\title{
17. CHANGES IN UPPER WATER-COLUMN STRUCTURE AT SITE 925, LATE MIOCENE- PLEISTOCENE: PLANKTONIC FORAMINIFER ASSEMBLAGE AND ISOTOPIC EVIDENCE ${ }^{1}$
}

\author{
W.P. Chaisson ${ }^{2}$ and A.C. Ravelo ${ }^{2}$
}

\begin{abstract}
The relative abundance of all planktonic foraminifer species and the $\delta^{18} \mathrm{O}$ and $\delta^{13} \mathrm{C}$ values of three species (Globigerinoides sacculifer, a mixed-layer dweller; Neogloboquadrina dutertrei, a thermocline dweller; and Truncorotalia crassaformis, a deep dweller) was determined in 25 samples at 250 k.y. intervals through the last 6 m.y. at Ocean Drilling Program Site 925. Combined, the data indicate that mixed-layer depth was a minimum at the end of the early Pliocene (4.0 Ma) and gradually increased toward the Pleistocene.

The $\delta^{18} \mathrm{O}$ and $\delta^{13} \mathrm{C}$ gradients in the mixed layer and the thermocline were derived by subtracting isotopic values of Globigerinoides sacculifer from Neogloboquadrina dutertrei and values of $N$. dutertrei from Truncorotalia crassaformis. Changes in $\delta^{18} \mathrm{O}$ gradients were used as a proxy record for variation in thermocline strength and position, while changes in $\delta^{13} \mathrm{C}$ gradients served a like purpose for productivity variation.

The early Pliocene was characterized by relatively high numbers of thermocline-dwelling taxa, relatively small mixed-layer $\delta^{18} \mathrm{O}$ gradients, and relatively large $\delta^{13} \mathrm{C}$ gradients. These indicators suggest that downwelling was at a minimum for the last 6 m.y. during this period at Site 925, the temperature difference between G. sacculifer and N. dutertrei habitats was small, and surface productivity was relatively great. After $2.5 \mathrm{Ma}$ thermocline-dwelling species' numbers were relatively low, mixed-layer $\delta^{18} \mathrm{O}$ gradients were relatively large, and mixed-layer $\delta^{13} \mathrm{C}$ were relatively small. The increased pole-to-equator temperature gradient that accompanied the growth of Northern Hemisphere ice sheets caused the intertropical convergence zone to move toward the equator and exert a growing influence at Site 925 through the last 4 m.y.
\end{abstract}

\section{INTRODUCTION AND BACKGROUND \\ Depth Ecology of Planktonic Foraminifers}

A striking and useful aspect of planktonic foraminifer ecology is the vertical stratification of population maxima in the water column. The character of planktonic foraminifer assemblages is determined by the thermal structure and nutrient distribution in the upper water column. Depth stratification of species in the water column has been verified by numerous workers with respect to both modern thermal structure and nutrient distribution (e.g., Emiliani, 1954, 1971; Bé, 1960; Lidz et al., 1968; Bé et al., 1971; Shackleton and Vincent, 1978; Williams et al., 1979; Durazzi, 1981; Deuser et al., 1981; Fairbanks and Wiebe, 1980; Fairbanks et al., 1980, 1982; Deuser, 1987; Kroon and Ganssen, 1988; Deuser and Ross, 1989) and paleo-conditions (Shackleton, 1967; Douglas and Savin, 1978; Keller, 1985; Gasperi and Kennett, 1992, 1993; Norris et al., 1993, 1994; Hodell and Vayavananda, 1993). When the thermocline shoals in the photic zone, thermocline-dwelling foraminifers become a relatively larger percentage of the assemblage (Leckie, 1989). Different thermoclinedwelling species favor various levels of productivity (Fairbanks and Wiebe, 1980). The details of depth ecology are far from completely understood. The depth habitat of some species definitely changes during their ontogeny (e.g., Lohmann and Schweitzer, 1990), while the depth ecologies of some extinct species are still undetermined.

Vertical stratification is probably an adaptive strategy for partitioning resources. The partitioning of resources for maximum utilization by the largest possible number of organisms has often been observed in ecological communities (MacArthur et al., 1966; Ricklefs, 1979). The physiological mechanism in planktonic foraminifers that maintains this stratification is not known. However, collections made

${ }^{1}$ Shackleton, N.J., Curry, W.B., Richter, C., and Bralower, T.J. (Eds.), 1997. Proc. ODP, Sci. Results, 154: College Station, TX (Ocean Drilling Program).

${ }^{2}$ Institute of Marine Sciences, University of California, Santa Cruz, CA 95064 U.S.A. chaisson@aphrodite.ucsc.edu in several locations around the world have consistently documented similar relative positions in the water column for several species, and $\delta^{18} \mathrm{O}$ measurements generally corroborate tow-net and sediment-trap observations. A short coming of many of the older studies is that the depth rankings were not made with respect to thermal structure, but rather were made with respect to absolute depth. The absolute depth of a particular species habitat may vary greatly from one location to another depending on position of the seasonal thermocline (mean state or seasonal variation). For example, a species that lives at thermocline depths, such as Menardella (=Globorotalia) menardii, may be listed as a shallow or surface dweller in locations where the thermocline is near the surface and as an "intermediate" dweller in locations were the thermocline is deep. In this study the depth habitats of all species are described with respect to thermal structure.

Many extinct Pliocene species are the immediate ancestors of modern species. Where their ranges overlap in the fossil record, they often show covarying abundances, suggesting similar ecological niche boundaries. Isotopic measurements in some cases confirm that extinct species occupied depth habitats similar to those of closely related modern species (e.g., Neogloboquadrina acostaensis and N. dutertrei in Keller, 1985). Given these similarities, extant and extinct species have been combined in faunal groups to produce continuous faunal records (Dowsett and Poore, 1990).

\section{Climatic and Oceanographic History}

The West Antarctic ice sheet was established in the late Miocene (Shackleton and Kennett, 1975; Ciesielski et al., 1982; Haq, 1984). During the latest Miocene, the Mediterranean was isolated ("the Messinian salinity crisis") by falling sea levels, a consequence of the Antarctic ice volume increase (Shackleton and Kennett, 1975; McKenzie and Oberhänsli, 1985; Hodell et al., 1986). Except for an episode of strong glaciation between 4.6 and 4.3 Ma (Jansen et al., 1993), the period from 5.0 to 3.2 Ma was one of climatic warmth and general stability in the size of Antarctic ice sheets (Shackleton and Opdyke, 1977; Keigwin, 1979, 1982; Jansen et al., 1993). High-lati- 
tude surface water seems to have warmed, while low-latitude water seems to have become relatively cool through this interval (Kennett and von der Borch, 1986). It was while the globe was in this climatic state that the tectonic uplift made the Isthmus of Panama subaerial, cutting off the low-latitude interoceanic connection between the $\mathrm{Pa}$ cific and Atlantic basins (Berggren and Hollister, 1977; Thunell and Belyea, 1982). The final closing of the Central American seaway may have taken place in the mid-Pliocene (Kaneps, 1979; Keigwin, 1978, 1982; Duque-Caro, 1990), but Coates et al. (1992), using near-shore marine records, have placed the final closing at 3.8-3.7 Ma, which is older than the 3.4-3.2 Ma estimate given by Keigwin $(1978,1982)$ based on pelagic records. Farrell et al. (1995) estimated, on the basis of carbonate records from several (Leg 138) sites in the eastern equatorial Pacific, that the seaway may have been effectively closed as early as $4.5 \mathrm{Ma}$.

The intensification of Northern Hemisphere cooling seems to have followed the closing of the seaway. Shackleton and Opdyke (1977) ascribed a large positive shift in the oxygen isotopic record on the Ontong Java Plateau at 3.2 Ma to the beginning of ice-sheet growth in the Northern Hemisphere, which agreed with an initial 3.0Ma age estimate for the first appearance of ice-rafted debris in North Atlantic sediments (Berggren, 1972; Poore, 1981). Re-evaluation of biostratigraphy at Deep Sea Drilling Project (DSDP) Sites 111 and 116 caused Backman (1979; Shackleton et al., 1984) to date the first appearance of ice-rafted debris in North Atlantic sediments at about $2.5 \mathrm{Ma}$. However, $\delta^{18} \mathrm{O}$ data from Site 806 in the western equatorial Pacific (Jansen et al., 1993) suggest that ice sheet growth was not a steady expansion from the 3.2 Ma enrichment, but rather a more complex enrichment pattern beginning after 3.7 Ma.
Other studies of North Atlantic records suggest that the interval from 3.1 to $2.45 \mathrm{Ma}$ showed a trend toward progressively cooler seasurface temperatures with increasing amplitude changes (Dowsett and Poore, 1990), and that cold episodes after 2.95 Ma began to be colder than the modern climate, but the warm intervals were also still significantly warmer (Raymo et al., 1992). After 2.5 Ma, a permanent enrichment of oxygen isotope values in North Atlantic DSDP cores marked what is probably the beginning of Northern Hemisphere glaciation (Thunell and Williams, 1983; Raymo et al., 1989). In this paper we will interpret changes in tropical planktonic foraminifer assemblages at Ocean Drilling Program (ODP) Site 925 as responses to changes in the position of the thermocline in the photic zone and consequent changes in the productivity of the upper water column from the late Miocene to the Pleistocene.

\section{METHODOLOGY}

This paper examines faunal and isotopic data at Site 925 in the western tropical Atlantic (Fig. 1) with a sampling interval of about 250 k.y. (Table 1). Absolute ages are assigned to samples using the astrochronologically tuned age models of Tiedemann and Franz (this volume), Bickert et al. (Chapter 16, this volume), and Shackleton and Crowhurst (this volume). Planktonic foraminifers are counted in 25 samples. Stable isotopes for Globigerinoides sacculifer, Neogloboquadrina dutertrei and Truncorotalia crassaformis are measured in the same samples. The difference between the $\delta^{18} \mathrm{O}$ values of $G$. sacculifer and $N$. dutertrei (mixed-layer [ML] $\Delta \delta^{18} \mathrm{O}$ ) are taken to represent the temperature difference between the surface and the ther-

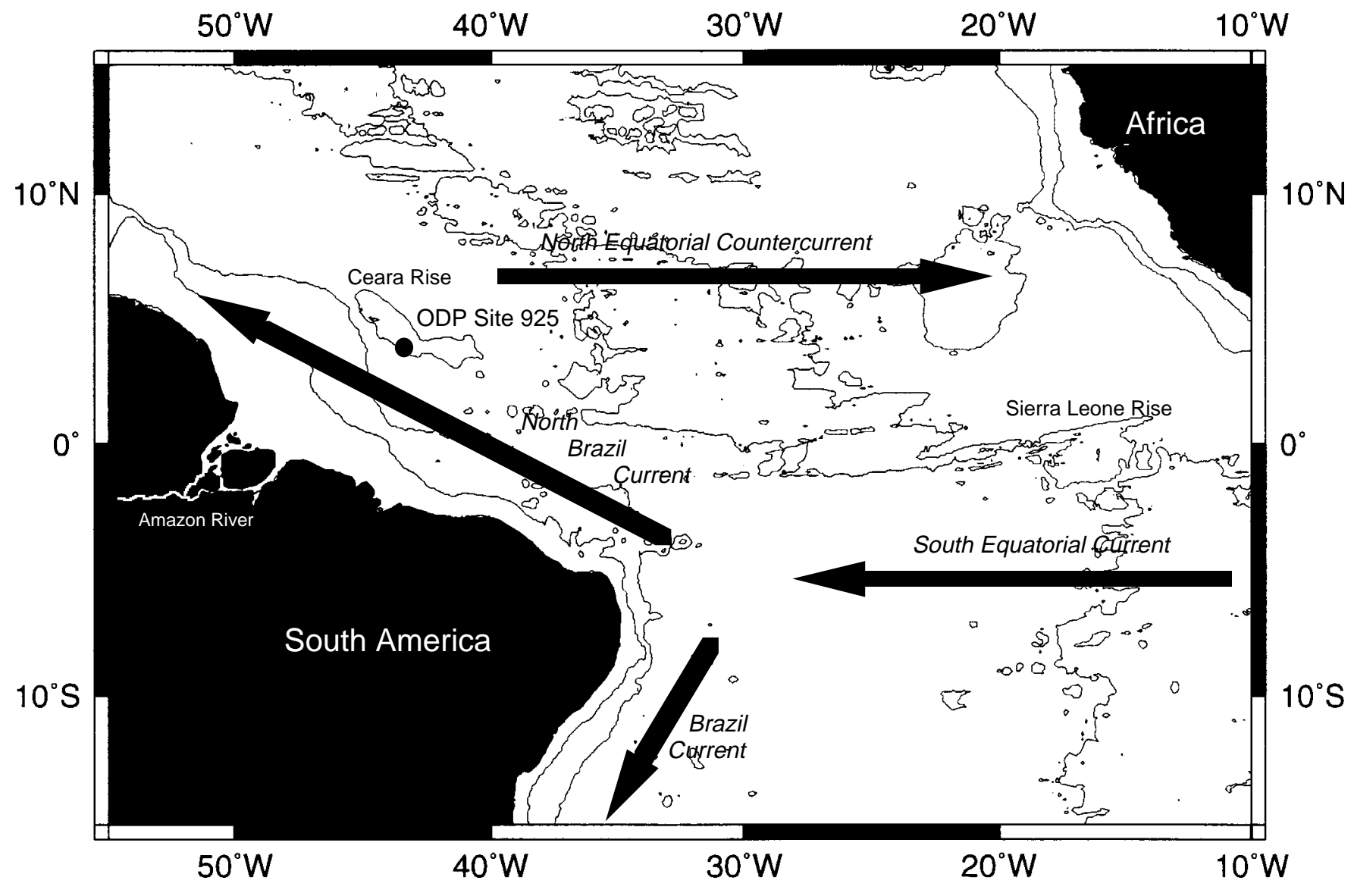

Figure 1. Location of Site 925 in the western tropical Atlantic. 
Table 1. Sample depths and ages at Site 925.

\begin{tabular}{|c|c|c|}
\hline $\begin{array}{l}\text { Core, section, } \\
\text { interval }(\mathrm{cm})\end{array}$ & $\begin{array}{l}\text { Depth } \\
\text { (mbsf) }\end{array}$ & $\begin{array}{l}\text { Tuned age } \\
\text { (Ma) }\end{array}$ \\
\hline \multicolumn{3}{|l|}{$154-925-$} \\
\hline $1 \mathrm{H}-1,65-67$ & 0.65 & 0.01 \\
\hline $2 \mathrm{H}-3,65-67$ & 8.15 & 0.22 \\
\hline $3 \mathrm{H}-2,65-67$ & 16.15 & 0.47 \\
\hline $4 \mathrm{H}-1,65-67$ & 24.15 & 0.75 \\
\hline $4 \mathrm{H}-6,65-67$ & 31.65 & 1.01 \\
\hline $5 \mathrm{H}-5,65-67$ & 39.65 & 1.30 \\
\hline $6 \mathrm{H}-3,55-57$ & 46.05 & 1.52 \\
\hline $7 \mathrm{H}-2,65-67$ & 54.15 & 1.80 \\
\hline $7 \mathrm{H}-6,65-67$ & 60.18 & 2.00 \\
\hline $8 \mathrm{H}-5,65-67$ & 68.15 & 2.24 \\
\hline $9 \mathrm{H}-3,65-67$ & 74.65 & 2.49 \\
\hline $10 \mathrm{H}-2,65-67$ & 82.65 & 2.77 \\
\hline $10 \mathrm{H}-6,65-67$ & 88.65 & 3.07 \\
\hline $11 \mathrm{H}-5,65-67$ & 96.65 & 3.25 \\
\hline $12 \mathrm{H}-3,65-67$ & 103.15 & 3.49 \\
\hline $13 \mathrm{H}-1,66-68$ & 109.66 & 3.78 \\
\hline $13 \mathrm{H}-5,73-75$ & 115.73 & 3.97 \\
\hline $14 \mathrm{H}-3,65-67$ & 122.15 & 4.19 \\
\hline $14 \mathrm{H}-7,10-12$ & 127.60 & 4.36 \\
\hline $15 \mathrm{H}-5,65-67$ & 134.65 & 4.71 \\
\hline $16 \mathrm{H}-3,65-67$ & 141.15 & 4.99 \\
\hline $17 \mathrm{H}-1,65-67$ & 147.65 & 5.31 \\
\hline $17 \mathrm{H}-5,65-67$ & 153.65 & 5.57 \\
\hline $18 \mathrm{H}-3,66-68$ & 160.16 & 5.92 \\
\hline $19 \mathrm{H}-1,65-67$ & 166.65 & 6.14 \\
\hline
\end{tabular}

Note: Tuned ages are derived from astrochronologic age models produced by Bickert et al. (Chapter 16, this volume), Tiedemann and Franz (this volume), and Shackleton and Crowhurst (this volume).

mocline, and the difference between $N$. dutertrei and T. crassaformis (thermocline $[\mathrm{TH}] \Delta \delta^{18} \mathrm{O}$ ) represent the temperature difference between the (seasonal) thermocline and sub-thermocline waters. These values are compared with changes in the faunal data in an attempt to locate the position of the thermocline relative to the photic zone. The timing of changes in the conjectured position of the thermocline through the last $6 \mathrm{~m}$.y. is considered as a possible response to climatic and oceanographic events set in motion by the closing of the Central American seaway and the onset of large-scale Northern Hemisphere glaciation.

\section{Sample Preparation}

Samples of $10 \mathrm{~cm}^{3}$ were collected shipboard at set intervals (one per core). Sample material was soaked in a neutral solution of water, Calgon, and hydrogen peroxide until it disaggregated. Sediment that did not disaggregate readily was agitated on a shaking table and/or placed on a hot plate equipped with a rotating magnet. Disaggregated sediment was wet sieved through a $63-\mu \mathrm{m}$ screen. The $>63-\mu \mathrm{m}$ fraction was dried either in an oven or on a hot plate $\left(<100^{\circ} \mathrm{C}\right)$.

Six to 10 specimens of each species were picked from the 355 $425-\mu \mathrm{m}$ fraction of each sample. Stable isotope measurements were made using a phosphoric acid bath at $90^{\circ} \mathrm{C}$ on a VG OPTIMA gas ratio mass spectrometer with an automated Isocarb carbonate reaction device attached. Precision of measurements is $0.05 \%$ o for carbon and $0.08 \%$ o for oxygen based on replicate standards. The values are reported relative to the Peedee belemnite (PDB) standard, and calibrations to PDB have been done using National Institute of Standard and Technology (NSB) 19 and the University of California, Santa Cruz in-house standards.

\section{Reconstruction of Water-column Structure}

Oxygen and carbon isotope ratios were measured for three planktonic species at $\sim 250-\mathrm{k}$.y. intervals through the last 6 m.y. At least three species were needed to characterize the structure of the upper water column: a mixed layer-, a thermocline-, and a deep-dwelling species to record the stable isotope values above, within and below the thermocline. Ravelo and Fairbanks (1992) introduced this strategy, using Globigerinoides sacculifer, Neogloboquadrina dutertrei, and Globorotalia tumida from core-top sediments to describe surface-water hydrography across the tropical Atlantic. They found that the range of $\delta^{18} \mathrm{O}$ values recorded in foraminiferal calcite was proportional to the observed temperature differences between the surface and the bottom of the photic zone at three sites with different hydrographic regimes (Ravelo and Fairbanks, 1992).

It is generally accepted that the oxygen isotopes of Globigerinoides sacculifer record conditions in the surface mixed layer (e.g., Shackleton and Vincent, 1978). Ecologic studies of modern G. sacculifer suggest that it does not spend its entire life cycle in the mixed layer, but may enter the upper thermocline to reproduce (Berger, 1971; Hemleben et al., 1989). Lohmann (1995) has shown that interpretation of the isotopic signal of some specimens of $G$. sacculifer may be complex due to the accretion of gametogenic calcite and partial dissolution of primary calcite. Isotopic analyses in this study were performed only on non-saccate specimens of G. sacculifer. G. sacculifer was present in all 25 samples examined.

The oxygen isotopic record of Neogloboquadrina dutertrei represents conditions in the thermocline (Curry and Matthews, 1981). Tow-netting (Jones, 1967; Fairbanks and Wiebe, 1980; Fairbanks et al., 1982) and sediment-trap work (Thunell et al., 1983; Curry et al., 1983; Thunell and Reynolds, 1984) have revealed that this species is closely associated with the nutricline, which is found in the upper part of the thermocline where the rapid change in water density slows the sinking rate phytoplankton creating a maximum concentration (Fairbanks and Wiebe, 1980). Ravelo and Fairbanks (1992) suggested that $N$. dutertrei calcifies at the same temperature on opposite sides of the tropical Atlantic, apparently remaining near the thermocline regardless of its depth. Curry and Matthews (1981) examined core-top material in the Indian Ocean and found that $N$. dutertrei calcifies at approximately $20^{\circ} \mathrm{C}$ through a wide range of depths. There are also data to support the assumption of the isothermy of $N$. dutertrei depth habitat in the Pleistocene (Ravelo and Fairbanks, 1992), but in the Pliocene there is no data at present. The above studies were done in the low latitudes, and in higher latitudes $N$. dutertre $i$ is found in water cooler than $20^{\circ} \mathrm{C}$ (Bé, 1977). The $20^{\circ} \mathrm{C}$ value is here regarded as a tropical asymptote; $N$. dutertre $i$ was assumed not to calcify in warmer water. N. dutertrei was present in 21 out of 25 samples examined. Specimens of sufficient size were not found at 4.71, 5.57, 5.92, and 6.14 Ma.

The deep-dwelling foraminifer most frequently present at Site 925 was Truncorotalia crassaformis. It appeared in 15 out of 25 samples in two stratigraphically disjunct and isotopically different ranges. Modern thermocline depth in the Ceara Rise region is $100-150 \mathrm{~m}$ below sea surface (Molinari and Johns, 1994). This hydrographic condition prevents a large supply of nutrients from reaching the photic zone, where they can be absorbed into the pelagic food web by phytoplankton. Consequently the 'rain' of organic matter to the zone below the thermocline at Site 925 has probably been very light through some of the last 6 m.y. and has sustained only low numbers of planktonic foraminifers adapted to a habit at the bottom of the thermocline.

The oxygen isotope signal includes both global ice volume and local temperature components. All species experience the ice-volume effect equally because the ratio of ${ }^{18} \mathrm{O}$ to ${ }^{16} \mathrm{O}$ changes universally at time scales greater than the mixing time of the world ocean $(500-600$ yr). However, each species records the temperature of its immediate environment uniquely. Therefore, if one species' isotope value is subtracted from another, then the difference will be equivalent to the temperature difference of their respective records (Berger et al., 1978), assuming that the ice-volume components of the isotope signal are equal. 
"Difference curves" were calculated and presented as proxies for the temperature differences between the depths of calcification for three species. The equation

$$
\operatorname{ML} \Delta \delta^{18} \mathrm{O}=N \text {. dutertrei } \delta^{18} \mathrm{O}-\text { G. sacculifer } \delta^{18} \mathrm{O}
$$

represents the temperature range between the sea surface and the thermocline (ML $\Delta \delta^{18} \mathrm{O}$ ). The equation

$$
\mathrm{TH} \Delta \delta^{18} \mathrm{O}=\text { T. crassaformis } \delta^{18} \mathrm{O}-N \text {. dutertrei } \delta^{18} \mathrm{O}
$$

represents the temperature range from the thermocline into the water below it (TH $\left.\Delta \delta^{18} \mathrm{O}\right)$.

It is the rate of temperature change in the upper water column (i.e., the character of the thermocline) that serves as the organizing parameter for populations of planktonic foraminifer species (Fairbanks and Wiebe, 1980; Ravelo et al., 1990; Ravelo and Fairbanks, 1992). If we inspect depth rankings of planktonic foraminifers from different locations in the modern ocean, they are generally similar in order, but the $\delta^{18} \mathrm{O}$ values that bracket the limits of each species' depth range vary widely (e.g., compare Shackleton and Vincent, 1978 and Deuser, 1987). The $\delta^{18} \mathrm{O}$ values in a given sample correspond to relative water temperature, but the depth ranking order of the assemblage is determined by the structure of the upper water column with only secondary regard for temperature (Ravelo and Fairbanks, 1992).

Basic to the interpretation of carbon isotope records is the assumption that lower $\delta^{13} C_{\text {carbonate }}$ values represent more nutrient-rich conditions. Organisms (and organic matter) are enriched in ${ }^{12} \mathrm{C}$ due to fractionation by metabolic processes. Oxidation of organic matter by actively feeding organisms and by heterotrophic bacteria releases ${ }^{12} \mathrm{C}$ back into the environment (Berger et al., 1978). ML $\Delta \delta^{13} \mathrm{C}$ describes the gradient of $\delta^{13} \mathrm{C}$ value in the mixed layer. Steep $\delta^{13} \mathrm{C}$ gradients indicate strong stratification between $G$. sacculifer and $N$. dutertrei habitats. TH $\Delta \delta^{13} \mathrm{C}$ describes the $\delta^{13} \mathrm{C}$ gradient between $N$. dutertrei and $T$. crassaformis habitats.

In this study the influence of salinity on isotopic values is assumed to be minor, although it is conceivable that the southward migration of the intertropical convergence zone (ITCZ) and its attendant rain could lower the oxygen isotopic values of $G$. sacculifer at Site 925.

For the faunal counts the $>150-\mu \mathrm{m}$ fraction was separated from the dried sample with a dry sieve. This fraction was divided with an Otto microsplitter until there was an amount small enough to evenly cover a picking tray. The picking tray was scored to divide its surface into quadrates. All specimens in a given quadrate were identified to species and removed to a gummed archive slide. To assure an unbiased collection of specimens, quadrates were cleared in a random pattern across the tray until $>300$ specimens had been counted (Imbrie and Kipp, 1971).

Low-resolution data do not preserve the high-frequency variation that is inherent in both the faunal and isotopic records. An estimate of variance is made for all the Site 925 data presented by using high-resolution data sets from other tropical sites. Although the variance around the observed value is probably not normally distributed, a standard deviation was calculated, and an error of two standard deviations is included in Figures 2-7. This technique smooths the data and preserves only the larger trends. Obviously it is optimal to have an estimate of variability based on data from the same site, but failing that it is better to use the variability observed at other sites, rather than have no estimate of error at all.

The taxonomy of Kennett and Srinivasan (1983) is largely followed in this study with modifications noted in Chaisson and Leckie (1993) and Chaisson and Pearson (this volume).

\section{RESULTS \\ Isotopic Records}

Globigerinoides sacculifer $\delta^{18} \mathrm{O}$ values at Site 925 do not change significantly between 6.14 and $2.49 \mathrm{Ma}$ (Fig. 2; Table 2). The average value is $-1.59 \%$ o through this interval. After 2.49 Ma the average value of G. sacculifer $\delta^{18} \mathrm{O}(-0.82 \%$ ) $)$ is higher. Neogloboquadrina dutertrei $\delta^{18} \mathrm{O}$ record follows a pattern similar to that of $G$. sacculifer (Fig. 2; Table 2), but the values are slightly higher, averaging $-1.00 \%$ o between 5.31 and $2.49 \mathrm{Ma}$, and increasing to $-0.02 \%$ ofter $2.49 \mathrm{Ma}$.

Unlike G. sacculifer and N. dutertrei, Truncorotalia crassaformis $\delta^{18} \mathrm{O}$ decreases through the Pliocene portion of its range (Fig. 2; Table 2). The average value of T. crassaformis $\delta^{18} \mathrm{O}$ in the early to late Pliocene (3.97-2.24 Ma) is $0.46 \%$, but in the late Pliocene to Pleistocene (2.35-1.91 Ma) the average value increases to $2.29 \%$. A similar large increase in the value of all truncorotaliids is observed in the late Pliocene of the southwest Pacific (Spencer-Cervato, pers. comm., 1995).

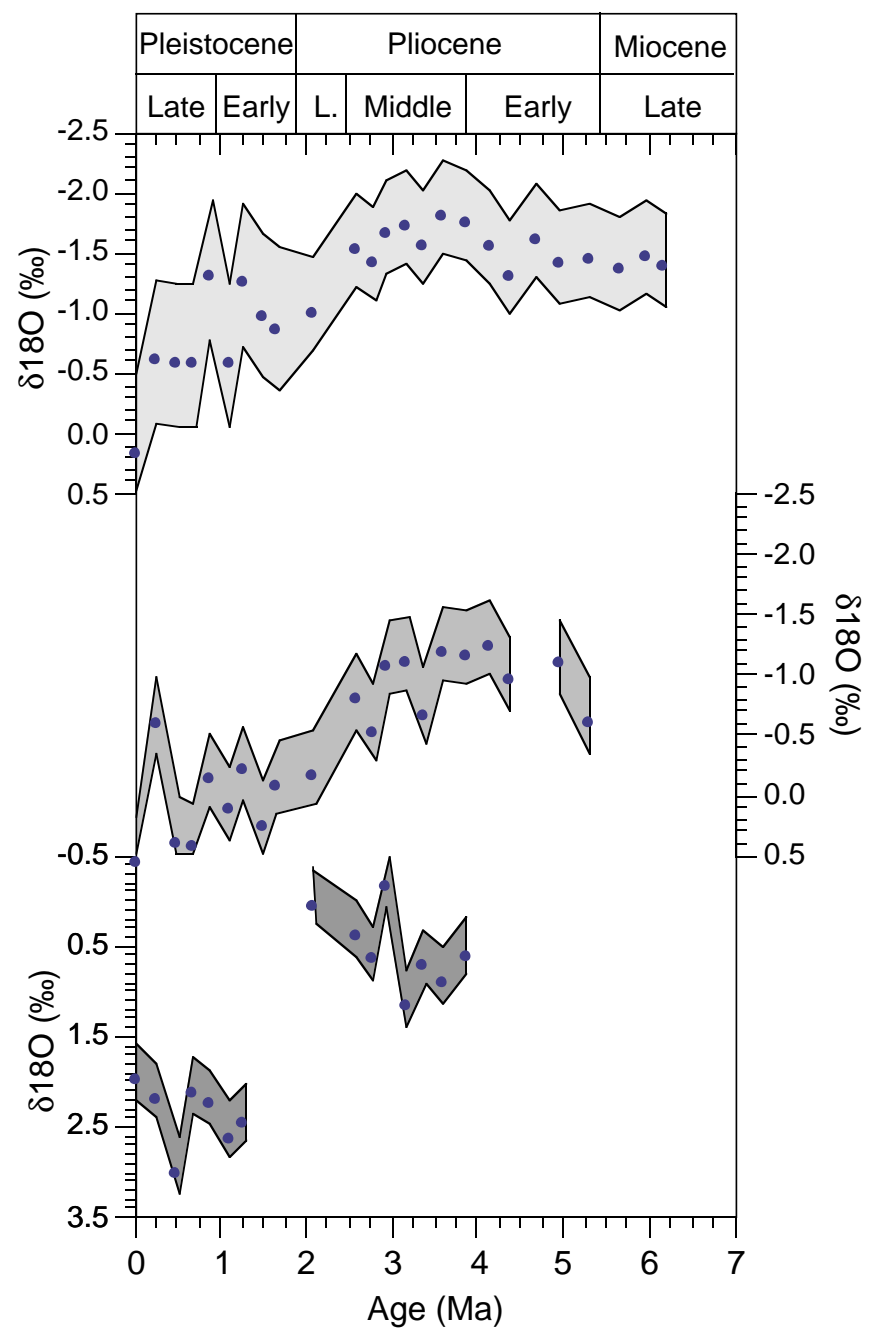

Figure 2. Oxygen isotope curves for Globigerinoides sacculifer (upper, light gray), Neogloboquadrina dutertrei (middle, medium gray), and Truncorotalia crassaformis (lower, dark gray). Gray areas around points are an estimate of variability derived from high resolution data provided by Jansen et al. (1993) and Billups et al. (this volume). 
Table 2. Oxygen isotope values.

\begin{tabular}{lrrrrr}
\hline Age (Ma) & \multicolumn{1}{l}{ sac } & \multicolumn{1}{c}{ dut } & cra & ML & TH \\
\hline 0.01 & 0.11 & 0.51 & 1.91 & 0.40 & 1.80 \\
0.22 & -0.67 & -0.66 & 2.12 & 0.01 & 2.79 \\
0.47 & -0.64 & 0.33 & 2.92 & 0.97 & 3.57 \\
0.75 & -0.64 & 0.37 & 2.04 & 1.01 & 2.69 \\
1.01 & -1.36 & -0.20 & 2.17 & 1.16 & 3.52 \\
1.30 & -0.65 & 0.06 & 2.54 & 0.71 & 3.20 \\
1.52 & -1.31 & -0.27 & 2.35 & 1.04 & 3.66 \\
1.80 & -1.05 & 0.20 & & 1.25 & \\
2.00 & -0.94 & -0.14 & & 0.79 & \\
2.24 & -1.07 & -0.22 & -0.03 & 0.84 & 1.04 \\
2.49 & -1.59 & -0.84 & 0.32 & 0.75 & 1.91 \\
2.77 & -1.47 & -0.59 & 0.57 & 0.88 & 2.05 \\
3.07 & -1.72 & -1.14 & -0.23 & 0.58 & 1.49 \\
3.25 & -1.78 & -1.15 & 1.07 & 0.63 & 2.86 \\
3.49 & -1.62 & -0.73 & 0.63 & 0.89 & 2.25 \\
3.78 & -1.87 & -1.25 & 0.83 & 0.62 & 2.70 \\
3.97 & -1.81 & -1.23 & 0.52 & 0.58 & 2.32 \\
4.19 & -1.62 & -1.31 & & 0.31 & \\
4.36 & -1.37 & -1.01 & & 0.36 & \\
4.71 & -1.68 & & & & \\
4.99 & -1.48 & -1.15 & & 0.33 & \\
5.31 & -1.51 & -0.67 & & 0.85 & \\
5.57 & -1.42 & & & & \\
5.92 & -1.54 & & & & \\
6.14 & -1.44 & & & & \\
& & & & &
\end{tabular}

Notes: sac $=$ Globigerinoides sacculifer $;$ dut $=$ Neogloboquadrina dutertrei $;$ cra $=$ Trun corotalia crassaformis; $\mathrm{ML}=[N$. dutertrei - Gs. sacculifer $] ; \mathrm{TH}=[$ Gr. crassaformis $-N$. dutertrei].

G. sacculifer $\delta^{13} \mathrm{C}$ values at Site 925 decline from $2.97 \%$ at 6.2 Ma to $1.76 \%$ at $2.24 \mathrm{Ma}$ (Fig. 3; Table 3). G. sacculifer and N. dutertrei $\delta^{13} \mathrm{C}$ values converge slightly between 5.31 and $3.07 \mathrm{Ma}$ (Fig. 3; Table 3). After a transitional period between 3.07 and $2.00 \mathrm{Ma}$, they converge very closely.

Compared with its $\delta^{18} \mathrm{O}$ values, the $T$. crassaformis $\delta^{13} \mathrm{C}$ record changes very little at Site 925 (Figs. 2, 3). In the Pliocene it generally parallels the $N$. dutertrei $\delta^{13} \mathrm{C}$ record, and in the Pleistocene it follows the oscillations in G. sacculifer and $N$. dutertrei $\delta^{13} \mathrm{C}$ values up to $0.47 \mathrm{Ma}$, whereafter it diverges toward more negative values. Overall the $\delta^{13} \mathrm{C}$ record of $T$. crassaformis shows a slight negative drift, less pronounced than that of $G$. sacculifer, and opposite that of $N$. dutertrei.

The difference between $N$. dutertrei and G. sacculifer $\delta^{18} \mathrm{O}(\mathrm{ML}$ $\Delta \delta^{18} \mathrm{O}$ ) is $0.4 \%$ at $4.99 \mathrm{Ma}$ and increases gradually until $1.80 \mathrm{Ma}$ (Fig. 4A; Table 2). From 1.80 Ma to the latest Pleistocene the difference generally decreases with one reversal of the trend between 1.30 $\mathrm{Ma}$ and $1.01 \mathrm{Ma}$.

ML $\Delta \delta^{13} \mathrm{C}$ changes little between 3.97 and 3.49 Ma (Fig. 4B; Table 3 ) and has an average value of $1.42 \%$. Values generally decline after 3.49 Ma, but seem to stabilize again after 2.00 Ma. The average value from the latest Pliocene through the Pleistocene is $0.45 \%$. The ML $\Delta \delta^{13} \mathrm{C}$ record is nearly a mirror image of the ML $\Delta \delta^{18} \mathrm{O}$ record.

The most prominent attribute of the TH $\Delta \delta^{18} \mathrm{O}$ curve is the very large positive shift recorded across the Pliocene/Pleistocene boundary, where it is unfortunately broken by the absence of $T$. crassaformis at 2.00 and $1.80 \mathrm{Ma}$ (Fig. 4C). While $N$. dutertrei $\delta^{18} \mathrm{O}$ values increase through this interval, the greater part of $\mathrm{TH} \Delta \delta^{18} \mathrm{O}$ change is due to the large Pleistocene increase in T. crassaformis $\delta^{18} \mathrm{O}$ values.

$\mathrm{TH} \Delta \delta^{13} \mathrm{C}$ has a trend toward increasing values after $3.07 \mathrm{Ma}$ (Fig. 4D). The coarseness and discontinuity of the record make further interpretation difficult.

\section{Faunal Abundance Records}

To compare the faunal record with the isotopic record at Site 925 and to make an estimate of the faunal response to hydrography in the Ceara Rise region through the last 6 m.y., counts of individual species

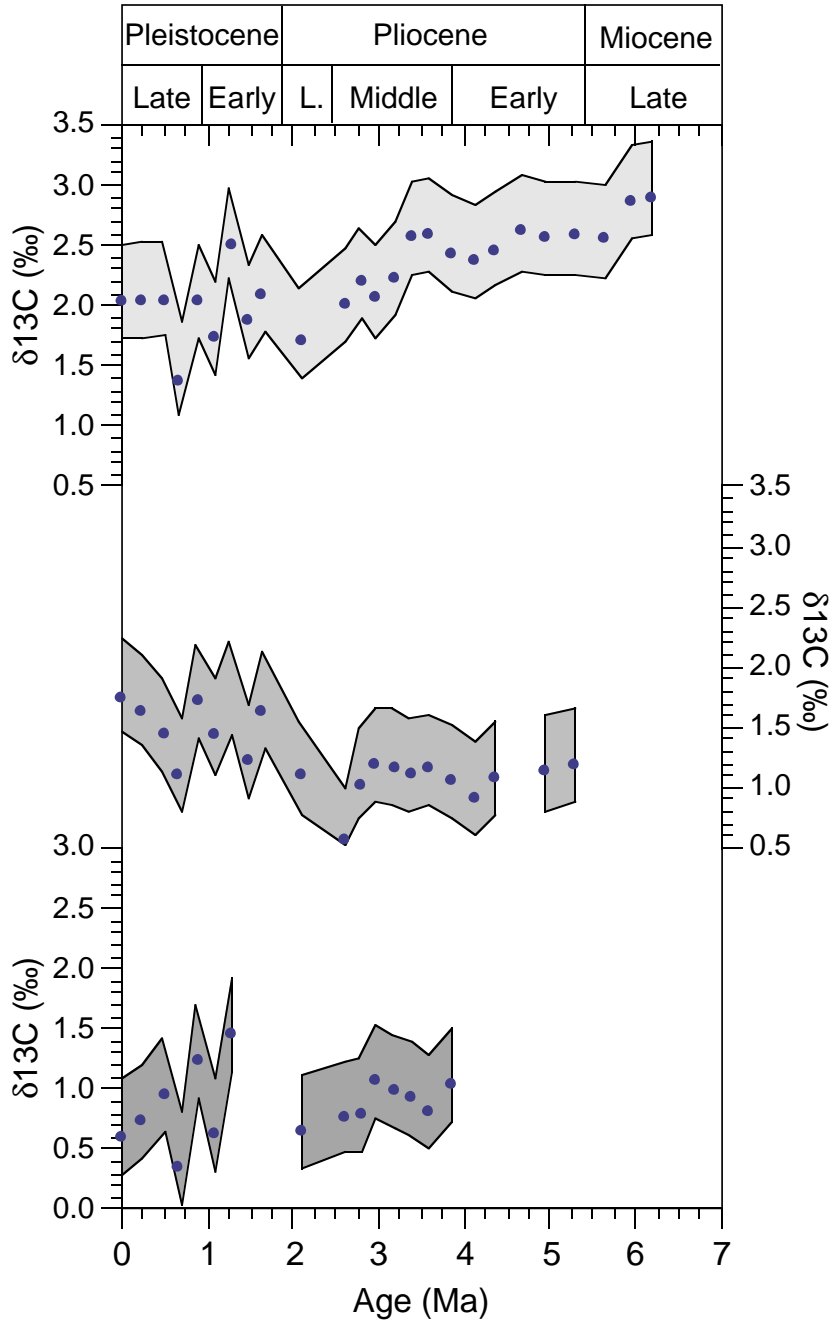

Figure 3. Carbon isotope curves for Globigerinoides sacculifer (upper, light gray), Neogloboquadrina dutertrei (middle, medium gray), Truncorotalia crassaformis (lower, dark gray). Gray areas around points are an estimate of variability derived from high resolution data in Billups et al. (this volume).

are combined into faunal groups (sensu "counting categories" of Dowsett and Poore, 1990). Percentage data for individual species is in Appendix A. Many of the extant planktonic foraminifer species have been present in the tropical oceans throughout the last 6 m.y., but there were several extinctions and first appearances in the midPliocene (Wei and Kennett, 1986). The groups assembled in this paper (Table 4) are after Dowsett and Poore (1990), who established covariance between the quantitative biostratigraphies of some Pliocene species and their modern descendants, and based on the phylogenetic relationships presented by Kennett and Srinivasan (1983).

\section{Stratigraphic Groups}

In addition to using ecological criteria to subdivide the planktonic foraminifers, the sediment assemblage is partitioned according to the stratigraphic range of each species. Taxa are classified as "MiocenePliocene" if their first appearance is before $7 \mathrm{Ma}$ and they become extinct before the Holocene. That is, most of their stratigraphic range is in the Miocene or earlier. Taxa are considered "Pliocene-Pleis- 
Table 3. Carbon isotope values.

\begin{tabular}{lccccr}
\hline Age (Ma) & sac & dut & cra & ML & TH \\
\hline 0.01 & 2.10 & 1.82 & 0.67 & -0.28 & -1.15 \\
0.22 & 2.11 & 1.71 & 0.80 & -0.40 & -0.91 \\
0.47 & 2.11 & 1.51 & 1.03 & -0.61 & -0.48 \\
0.75 & 1.45 & 1.17 & 0.41 & -0.28 & -0.76 \\
1.01 & 2.09 & 1.77 & 1.30 & -0.32 & -0.47 \\
1.30 & 1.79 & 1.50 & 0.70 & -0.29 & -0.80 \\
1.52 & 2.58 & 1.82 & 1.52 & -0.77 & -0.30 \\
1.80 & 1.93 & 1.30 & & -0.64 & \\
2.00 & 2.16 & 1.71 & & -0.45 & \\
2.24 & 1.76 & 1.16 & 0.71 & -0.60 & -0.45 \\
2.49 & 2.09 & 0.61 & 0.83 & -1.48 & 0.22 \\
2.77 & 2.26 & 1.10 & 0.85 & -1.16 & -0.25 \\
3.07 & 2.12 & 1.26 & 1.13 & -0.86 & -0.13 \\
3.25 & 2.30 & 1.24 & 1.06 & -1.06 & -0.19 \\
3.49 & 2.62 & 1.17 & 1.00 & -1.45 & -0.17 \\
3.78 & 2.66 & 1.22 & 0.90 & -1.44 & -0.32 \\
3.97 & 2.50 & 1.12 & 1.11 & -1.38 & -0.02 \\
4.19 & 2.44 & 0.98 & & -1.47 & \\
4.36 & 2.53 & 1.15 & & -1.38 & \\
4.71 & 2.67 & & & & \\
4.99 & 2.62 & 1.20 & & -1.42 & \\
5.31 & 2.65 & 1.26 & & -1.40 & \\
5.57 & 2.62 & & & & \\
5.92 & 2.94 & & & & \\
6.14 & 2.97 & & & & \\
& & & & &
\end{tabular}

Notes: sac $=$ Globigerinoides sacculifer $;$ dut $=$ Neogloboquadrina dutertrei $;$ cra $=$ Trun corotalia crassaformis; $\mathrm{ML}=[N$. dutertrei - Gs. sacculifer $] ; \mathrm{TH}=[$ Gr. crassaformis $-N$. dutertrei].

tocene" if they appear after $7 \mathrm{Ma}$, but do not survive into the modern ocean. Taxa are called "extant" if they exist in the modern ocean, regardless of the time of their first appearance. See Table 5 for a species list.

Miocene-Pliocene taxa account for fully half of the assemblage from the bottom of the section to the middle Pliocene, declining slightly from nearly $60 \%$ at $4.71 \mathrm{Ma}$ to $50 \%$ at $3.78 \mathrm{Ma}$ (Fig. 4A; Table 6). At 2.61 and $2.49 \mathrm{Ma}$ the Pliocene fraction expands to maintain the Neogene component of the fauna (= Miocene-Pliocene + Pliocene-Pleistocene components) at $\sim 45 \%$, but both groups decline drastically between 2.49 and 2.24 Ma to only $10 \%$ of the assemblage. The expansion of the Pliocene-Pleistocene portion of the assemblage at 2.77 and $2.49 \mathrm{Ma}$ is due to large numbers (11\% and $13 \%$, respectively) of Globorotalia miocenica in those two samples. The slight recovery of the Miocene-Pliocene fraction at $2.49 \mathrm{Ma}$ is due largely to the Neogene globoturborotalitids (27\%) and Globigerinoides obliquus at $2.49 \mathrm{Ma}(23 \%)$.

\section{Mixed-layer Dwellers}

The dominant faunal elements of the mixed-layer dwellers include the Globigerinoides sacculifer group, Globigerinoides ruber group and Globigerinita glutinata. Dentoglobigerina altispira is significant during the early to middle Pliocene and Globoturborotalita rubescens is significant in the Pleistocene (Figs. 5, 6). From 5.31 to $3.07 \mathrm{Ma}$, mixed-layer dwellers make up about $60 \%$ of the planktonic foraminifer fauna. After $2.77 \mathrm{Ma}$, the abundance of this group increases through the late Pliocene to constitute nearly $80 \%$ of the assemblage through much of the Pleistocene.

The Globigerinoides ruber group constitutes $>30 \%$ of the assemblage at $5.92 \mathrm{Ma}$ and declines to a low of $15 \%$ at $4.71 \mathrm{Ma}$ (Fig. 6C; Table 6). It increases steadily from $4.71 \mathrm{Ma}$ to a high at $1.80 \mathrm{Ma}$, when it constitutes $50 \%$ of the planktonic foraminifer fauna. A steep decline to $10 \%$ at $0.75 \mathrm{Ma}$ is followed by a recovery to $>40 \%$ at the top of the section.

The abundance of the Globigerinoides sacculifer group increases sharply between 6.14 and $5.57 \mathrm{Ma}$ and then declines throughout the early and middle Pliocene, reaching a low at 2.49 Ma (Fig. 5D; Table 6). Two samples in the late Pliocene (2.00 Ma) and early Pleistocene $(1.80 \mathrm{Ma})$ have large numbers of the Globigerinoides sacculifer

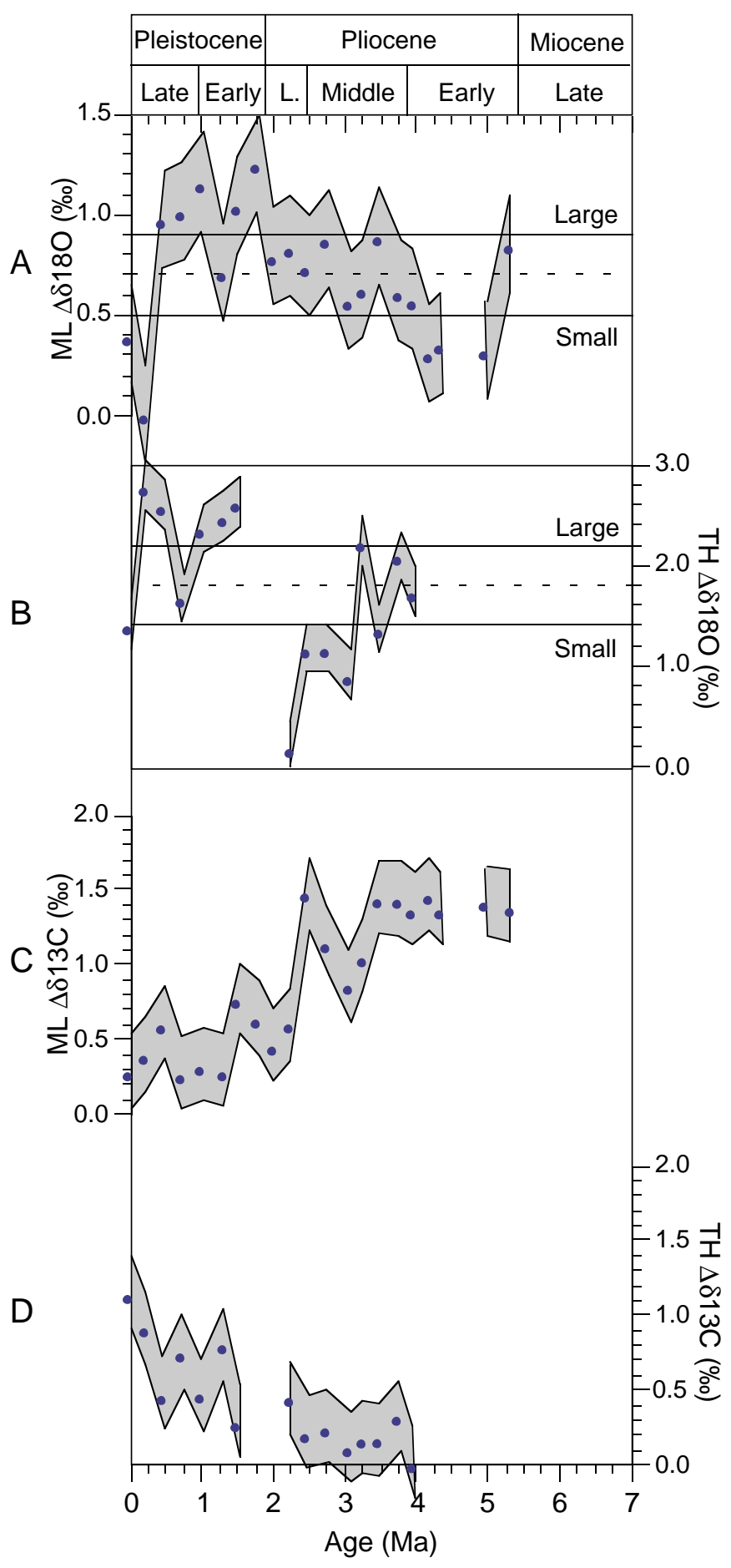

Figure 4. Oxygen and carbon isotope "difference" curves. A. Neogloboquadrina dutertrei $\delta^{18} \mathrm{O}-$ Globigerinoides sacculifer $\delta^{18} \mathrm{O}$. B. Truncorotalia crassaformis $\delta^{18} \mathrm{O}-$ Neogloboquadrina dutertrei $\delta^{18} \mathrm{O}$. C. N. dutertrei $\delta^{13} \mathrm{C}-G$. sacculifer $\delta^{13} \mathrm{C}$. D. T. crassaformis $\delta^{13} \mathrm{C}-N$. dutertrei $\delta^{13} \mathrm{C}$. Gray areas represent two standard deviations around data points, and are based on high resolution data provided by Jansen et al. (1993) and Billups et al. (this volume). 
Table 4. Species in faunal groups.

\begin{tabular}{lc}
\hline \multicolumn{1}{c}{ Mixed layer } & Thermocline \\
\hline Globigerinoides ruber group & Pulleniatinids \\
Globigerinoides ruber & Pulleniatina obliquiloculata \\
Globigerinoides obliquus & Pulleniatina primalis \\
Globigerinoides extremus & \\
Globigerinoides sacculifer group & Thermocline globorotaliids \\
Globigerinoides sacculifer & Menardella limbata \\
Globigerinoides trilobus & Menardella menardii \\
Globigerinoides quadrilobatus & Menardella miocenica \\
Globigerinoides fistulosus & Menardella multicamerata \\
Orbulina universa & Menardella pertenuis \\
& Hirsutella cibaonsis \\
Surface phytoplanktivore group & Hirsutella juanai \\
Globoturborotalita rubescens & Hirsutella margaritae \\
Globigerinita glutinata & Globoconella inflata \\
Dentoglobigerina altispira & Globoconella triangula \\
& Globorotalia plesiotumida \\
& Globorotalia merotumida \\
& Globorotalia tumida \\
& Neogene globoturborotalitids \\
& Globoturborotalita woodi \\
& Globoturborotalita apertura \\
& Globoturborotalita nepenthes \\
& Globoturborotalita decoraperta \\
& Tropical neogloboquadrinids \\
& Neogloboquadrina dutertrei \\
& Neogloboquadrina humerosa \\
& Neogloboquadrina acostaensis \\
\hline &
\end{tabular}

Table 5. Species in stratigraphic groups.

\begin{tabular}{|c|c|}
\hline Miocene-Pliocene taxa & Pliocene-Pleistocene taxa \\
\hline $\begin{array}{l}\text { Mixed-layer dwellers } \\
\text { Globigerinoides obliquus } \\
\text { Globigerinoides extremus } \\
\text { Globoquadrina baroemoenensis } \\
\text { Dentoglobigerina altispira }\end{array}$ & $\begin{array}{l}\text { Mixed-layer dwellers } \\
\text { Globigerinoides fistulosus } \\
\text { Beella praedigitata }\end{array}$ \\
\hline $\begin{array}{l}\text { Thermocline dwellers } \\
\text { Globoturborotalita nepenthes } \\
\text { Globoturborotalita decoraperta } \\
\text { Globoturborotalita apertura } \\
\text { Globoturborotalita woodi } \\
\text { Menardella limbata } \\
\text { Hirsutella cibaoensis } \\
\text { Hirsutella juanai } \\
\text { Globorotalia plesiotumida } \\
\text { Globorotalia merotumida } \\
\text { Neogloboquadrina acostaensis } \\
\text { Sphaeroidinellopsis seminulina } \\
\text { Sphaeroidinellopsis paenadehiscens } \\
\text { Sphaeroidinellopsis kochi } \\
\text { Globigerinella obesa }\end{array}$ & $\begin{array}{l}\text { Thermocline dwellers } \\
\text { Menardella miocenica } \\
\text { Menardella multicamerata } \\
\text { Hirsutella margaritae } \\
\text { Globoconella triangula } \\
\text { Neogloboquadrina humerosa } \\
\text { Pulleniatina primalis }\end{array}$ \\
\hline $\begin{array}{l}\text { Deep dwellers } \\
\text { Globoquadrina venezuelana* }\end{array}$ & $\begin{array}{l}\text { Deep dwellers } \\
\quad \text { Truncorotalia tosaensis }\end{array}$ \\
\hline $\begin{array}{l}\text { Extan } \\
\text { Mixed-layer dwellers } \\
\text { Globigerina falconensis } \\
\text { Globigerina bulloides } \\
\text { Globoturborotalita rubescens } \\
\text { Globoturborotalita tenulla } \\
\text { Globigerinoides sacculifer } \\
\text { Globigerinoides ruber } \\
\text { Orbulina universa } \\
\text { Globorotalia ungulata } \\
\text { Turborotalita quinqueloba } \\
\text { Turborotalita humilis } \\
\text { Beella digitata } \\
\text { Globigerinita glutinata } \\
\text { Globigerinella aequilateralis }\end{array}$ & $\begin{array}{l}\text { taxa } \\
\text { Thermocline dwellers } \\
\text { Globigerinoides conglobatus } \\
\text { Menardella menardii } \\
\text { Hirsutella scitula } \\
\text { Globoconella inflata } \\
\text { Globorotalia tumida } \\
\text { Neogloboquadrina pachyderma } \\
\text { Neogloboquadrina dutertrei } \\
\text { Pulleniatina obliquiloculata } \\
\text { Sphaeroidinella dehiscens } \\
\text { Globigerinella calida } \\
\text { Candeina nitida } \\
\text { Deep dwellers } \\
\text { Truncorotalia crassaformis } \\
\text { Truncorotalia truncatulinoides } \\
\text { Globorotaloides hexagona } \\
\text { Tenuitella }\end{array}$ \\
\hline
\end{tabular}

Notes: *Gasperi and Kennett $(1992,1993)$ suggest that this species may have become a mixed-layer dweller in the late Miocene. This depth ecology may have been maintained into the Pliocene. group, but the remainder of the Pleistocene numbers return to early to middle Pliocene levels.

Globigerinita glutinata is a small, non-spinose foraminifer with a micro-perforate test. Although it lives in the mixed layer, it is largely a phytoplanktivore (Hemleben et al., 1989), while the Globigerinoides are omnivores, including varying amounts of zooplankton in their diet (Bé et al., 1977; Hemleben and Spindler, 1983; Spindler et al., 1984; Hemleben et al., 1989). The peaks in its record do not correspond to those of the Globigerinoides (Figs. 6A, 5C, 5D).

From a low of $<5 \%$ at the bottom of the section, G. glutinata increases to reach peaks (>15\%) at $2.49 \mathrm{Ma}$ and at 3.97 Ma (Fig. 6A; Table 6). This trend is opposite that of the Globigerinoides sacculifer group and similar to that of the Globigerinoides ruber group, but $G a$. glutinata reaches a maximum earlier and declines abruptly to $<10 \%$ of the assemblage between 2.49 and $1.52 \mathrm{Ma}$, a period during which both Globigerinoides groups are plentiful. Similarly, it reaches a high of $>20 \%$ at 1.01 and $0.75 \mathrm{Ma}$, while the Globigerinoides groups are declining.

Globoturborotalita rubescens abundance peaks $(\sim 25 \%)$ at 0.75 $\mathrm{Ma}$, concordant with Globigerinita glutinata (Figs. 6A, 6B) and opposite the Globigerinoides groups (Figs. 6B, 5C, 5D). It decreases to $5 \%$ of the assemblage in the top two samples of the section during the recovery of the Globigerinoides groups.

Dentoglobigerina altispira disappeared globally at $\sim 3 \mathrm{Ma}$ and it declines abruptly to virtual extinction at Site 925 after reaching a maximum of $20 \%$ of the assemblage at $3.78 \mathrm{Ma}$ (Fig. 6C), an interval of low abundance for the Globigerinoides groups and a peak for Globigerinita glutinata. Thus two separate factions in the mixed layer group are apparent: the Globigerinoides and a group that includes Globigerinita glutinata and Globoturborotalita rubescens in the Pleistocene and G. glutinata and Dentoglobigerina altispira in the Pliocene. Dentoglobigerina is a genus with no modern descendants. Single specimens found in samples younger than 3.07 Ma at Site 925 are contaminants.

\section{Thermocline Dwellers}

Thermocline-dwelling foraminifers are most numerous in the early Pliocene (Fig. 7A; Table 6). They gradually decline in abundance from 4.71 Ma to latest Pleistocene, interrupted by brief recoveries to early Pliocene levels at 2.77 and $0.47 \mathrm{Ma}$. The decline from 2.77 to $1.52 \mathrm{Ma}$ is the most precipitous ( $\sim 50 \%$ to $\sim 10 \%)$. The coarse temporal resolution of this study likely misses other brief increases in thermocline-dwelling taxa in response to Pleistocene climatic fluctuations.

The tropical neogloboquadrinids include Neogloboquadrina $d u$ tertrei, $N$. humerosa and $N$. acostaensis. $N$. acostaensis is present in only two samples in the lower Pliocene at Site 925 and never exceeds $1 \%$ of the assemblage. The neogloboquadrinid group often (15 samples) accounts for $>10 \%$, but rarely (five samples) accounts for $>15 \%$ of the assemblage (Fig. 7B; Table 6). At $\sim 4.0 \mathrm{Ma}, N$. humerosa reaches $7 \%$ (its maximum) and $N$. dutertrei $12 \%$ of the assemblage, the maximum share for this group at Site 925 . Tropical neogloboquadrinids decline through the rest of the Pliocene to a minimum $(<5 \%)$ at $1.80 \mathrm{Ma}$ in the early Pleistocene with sharp recoveries to $\sim 15 \%$ at 3.07 and 2.24 Ma. In the Pleistocene, the group has two more similar recoveries at 0.96 and $0.47 \mathrm{Ma}$. Overall tropical neogloboquadrinid abundance varies inversely with respect to that of the Globigerinoides ruber group. This is to be expected for two groups that constitute eutrophic and oligotrophic end-members, respectively, of the ecological spectrum of planktonic foraminifer faunal groups.

"Thermocline" globorotaliids exclude Globorotalia ungulata, which is a mixed-layer denizen (Shackleton and Vincent, 1978) and Truncorotalia crassaformis, T. truncatulinoides, and T. tosaensis, which are all deep-dwelling taxa. Menardellid species are the dominant element of the group at Site 925, while tumidiform species are secondary and all other species (Hirsutella cibaoensis, H. margaritae 
Table 6. Faunal abundance percentages.

\begin{tabular}{|c|c|c|c|c|c|c|c|c|c|c|c|c|c|}
\hline \multirow[b]{2}{*}{ Faunal group } & \multicolumn{13}{|c|}{ Age (Ma) } \\
\hline & 0.01 & 0.22 & 0.47 & 0.75 & 1.01 & 1.30 & 1.52 & 1.80 & 2.00 & 2.24 & 2.49 & 2.77 & 3.07 \\
\hline \multicolumn{14}{|l|}{ Stratigraphic groups } \\
\hline Miocene-Pliocene & 0 & 0 & 0 & 0 & 2 & 1 & 3 & 2 & 3 & 5 & 30 & 34 & 23 \\
\hline Pliocene-Pleistocene & 0 & 2 & 0 & 0 & 0 & 0 & 0 & 2 & 0 & 4 & 13 & 11 & 7 \\
\hline Mixed-layer dwellers & 83 & 73 & 54 & 74 & 75 & 76 & 74 & 73 & 71 & 69 & 65 & 50 & 55 \\
\hline Thermocline dwellers & 9 & 25 & 45 & 24 & 24 & 20 & 26 & 14 & 28 & 30 & 34 & 49 & 43 \\
\hline Globigerinoides ruber group & 44 & 41 & 31 & 11 & 30 & 29 & 50 & 50 & 30 & 30 & 44 & 28 & 33 \\
\hline Globigerinoides sacculifer group & 19 & 24 & 9 & 9 & 14 & 24 & 10 & 17 & 38 & 35 & 3 & 6 & 12 \\
\hline Surface phytoplanktivores & 20 & 7 & 13 & 42 & 31 & 21 & 14 & 6 & 3 & 4 & 16 & 13 & 11 \\
\hline Pulleniatinids & 0 & 2 & 0 & 0 & 1 & 5 & 5 & 3 & 7 & 8 & 0 & 0 & 0 \\
\hline Neogene globoturborotalitids & 0 & 0 & 0 & 1 & 0 & 1 & 2 & 0 & 0 & 3 & 6 & 28 & 13 \\
\hline Thermocline globoturborotaliids & 0 & 11 & 23 & 12 & 1 & 0 & 4 & 1 & 7 & 0 & 14 & 12 & 8 \\
\hline \multirow[t]{2}{*}{ Tropical neogloboquadrinids } & 6 & 2 & 17 & 6 & 14 & 4 & 6 & 3 & 4 & 13 & 9 & 7 & 17 \\
\hline & \multicolumn{12}{|c|}{ Age (Ma) } & \\
\hline Faunal group & 3.25 & 3.49 & 3.78 & 3.97 & 4.19 & 4.36 & 4.71 & 4.99 & 5.31 & 5.57 & 5.92 & 6.14 & \\
\hline \multicolumn{13}{|l|}{ Stratigraphic groups } & \\
\hline Miocene-Pliocene & 50 & 39 & 52 & 45 & 52 & 52 & 59 & 50 & 49 & 48 & 58 & 66 & \\
\hline Pliocene-Pleistocene & 1 & 4 & 3 & 7 & 4 & 5 & 1 & 3 & 4 & 0 & 0 & 0 & \\
\hline Mixed-layer dwellers & 65 & 68 & 60 & 59 & 67 & 54 & 52 & 60 & 53 & 78 & 69 & 56 & \\
\hline Thermocline dwellers & 33 & 31 & 38 & 39 & 33 & 45 & 48 & 40 & 46 & 21 & 31 & 43 & \\
\hline Globigerinoides ruber group & 28 & 24 & 19 & 23 & 30 & 21 & 15 & 21 & 19 & 27 & 33 & 26 & \\
\hline Globigerinoides sacculifer group & 11 & 20 & 14 & 13 & 19 & 18 & 22 & 27 & 25 & 39 & 28 & 17 & \\
\hline Surface phytoplanktivores & 24 & 24 & 27 & 22 & 17 & 15 & 14 & 11 & 8 & 11 & 7 & 13 & \\
\hline Pulleniatinids & 0 & 0 & 0 & 0 & 1 & 0 & 0 & 0 & 0 & 0 & 0 & 0 & \\
\hline Neogene globoturborotalitids & 6 & 6 & 4 & 5 & 6 & 14 & 17 & 14 & 8 & 4 & 9 & 16 & \\
\hline Thermocline globoturborotaliids & 9 & 8 & 10 & 5 & 7 & 9 & 15 & 12 & 15 & 10 & 10 & 2 & \\
\hline Tropical neogloboquadrinids & 7 & 11 & 17 & 19 & 12 & 17 & 7 & 8 & 12 & 0 & 0 & 8 & \\
\hline
\end{tabular}

and Globoconella triangula) make minor, sporadic appearances. Thermocline globorotaliids compose $\sim 15 \%$ of the assemblage in peaks centered at 4.99 and $2.49 \mathrm{Ma}$, and $20 \%$ at $0.47 \mathrm{Ma}$, the latter corresponding to a peak in tropical neogloboquadrinid abundance (Fig. 4C; Table 6). Menardellid taxa make up the largest portion of the above-mentioned peaks. Between 2.24 and $1.52 \mathrm{Ma}$, when menardellid globorotaliids are very rare or absent, Globorotalia tumida appears in its greatest numbers (up to $5 \%$ of the assemblage).

Isotope work by Keller (1985) has identified Globoturborotalita woodi and Globoturborotalita nepenthes as "intermediate" dwellers. In the nomenclature of Savin and Douglas (1973), "intermediate" refers to species associated with the seasonal thermocline. The numbers of G. woodi and G. apertura fluctuate in concert at Site 925 and at sites in the tropical Pacific (Chaisson, 1995), and they intergrade morphologically (Chaisson and Leckie, 1993). G. apertura is treated here as a thermocline dweller. Lourens et al. (1992) regard it as a mixed-layer dweller based on its putative phylogenetic relationship to $G$. rubescens. That its chambers are generally more inflated than those of G. woodi lends credence to this argument (Hecht and Savin, 1972), but it will remain in its present category awaiting supporting isotopic evidence. $G$. woodi is always more common that any other globoturborotalitid at Site 925. Globoturborotalitid abundance oscillates between $15 \%$ and $5 \%$ between 6.14 and $2.24 \mathrm{Ma}$ (Fig 7D; Table 6). There is a broad paracme between 4.19 and $3.25 \mathrm{Ma}$, followed by a sharp recovery to $25 \%$ at $2.77 \mathrm{Ma}$. The overall pattern is quite similar to that observed at Ocean Drilling Program (ODP) Site 806 in the western equatorial Pacific (Chaisson, 1995).

A peak in Neogene globoturborotalitid numbers (15\%) at $4.71 \mathrm{Ma}$ is coupled with an absence at Site 925 of tropical neogloboquadrinids large enough for isotopic analysis. The pronounced decrease in globoturborotalitid abundance between 4.19 and $3.25 \mathrm{Ma}$ is centered around the minimum in Globigerinoides sacculifer $\delta^{18} \mathrm{O}$ values. This Neogene group declines to extinction when G. sacculifer and N. dutertrei $\delta^{18} \mathrm{O}$ values make their positive shift between 2.49 and 2.24 Ma.

The various pulleniatinids morphotypes do not show good stratigraphic integrity at ODP Site 925 as they do in the western equatorial
Pacific (Bolli and Saunders, 1985; Chaisson and Leckie, 1993). In the early and middle Pliocene, the pulleniatinid group is represented only by three left-coiling specimens Pulleniatina primalis at $4.14 \mathrm{Ma}$ in this study. Biostratigraphic work (Curry, Shackleton, Richter, et al., 1995) has shown that it occurs sporadically in low numbers up to the "Atlantic disappearance" at 3.5 Ma and reappears in the late Pliocene at 2.3 Ma, (Saito, 1976; Keigwin, 1982; Bolli and Saunders, 1985; Curry, Shackleton, Richter, et al., 1995) largely composed of $P$. obliquiloculata with rare specimens of $P$. primalis. The period of peak abundance of the pulleniatinid group (2.11-1.12 Ma) corresponds to minima in the numbers of other thermocline-dwelling taxa (Fig. 7D; Table 6). Peaks in other thermocline dwellers are coincident with the absence of pulleniatinids at 0.70 and $0.52 \mathrm{Ma}$ and the interval of greatest pulleniatinid abundance coincides with an interval of high Globigerinoides abundance. The pulleniatinid pattern of abundance is precisely the opposite of that of Globigerinita glutinata.

\section{DISCUSSION}

\section{Late Miocene and Pliocene}

Samples at Site 925 in which no tropical neogloboquadrinids of sufficient size for isotopic analysis were found (6.14 Ma), or no specimens at all were present (5.92 and 5.57 Ma; Figs. 3, 7B) correspond to periods of latest Miocene intensification of Antarctic glaciation between 6.1 and 5.9 Ma and centered at 5.6 Ma (Hodell and Kennett, 1986). The Globigerinoides ruber group constitutes about $30 \%$ of the assemblage in these three samples (Fig. 5C) and the Globigerinoides sacculifer group abundance increases steeply to $39 \%$ at $5.57 \mathrm{Ma}$ (Fig. 5D). In the modern ocean, increased numbers of Globigerinoides ruber are associated with oligotrophic conditions and increased numbers of Neogloboquadrina dutertrei are associated with eutrophic conditions (Bé, 1977; Hemleben et al., 1989; Ravelo et al., 1990). Faunal evidence, therefore, suggests that during the latest Miocene glacial periods, the thermocline at Site 925 in the western tropical Atlantic was deep in the photic zone. The cooling of the southern latitudes increased the pole-to-equator temperature gradient, strength- 


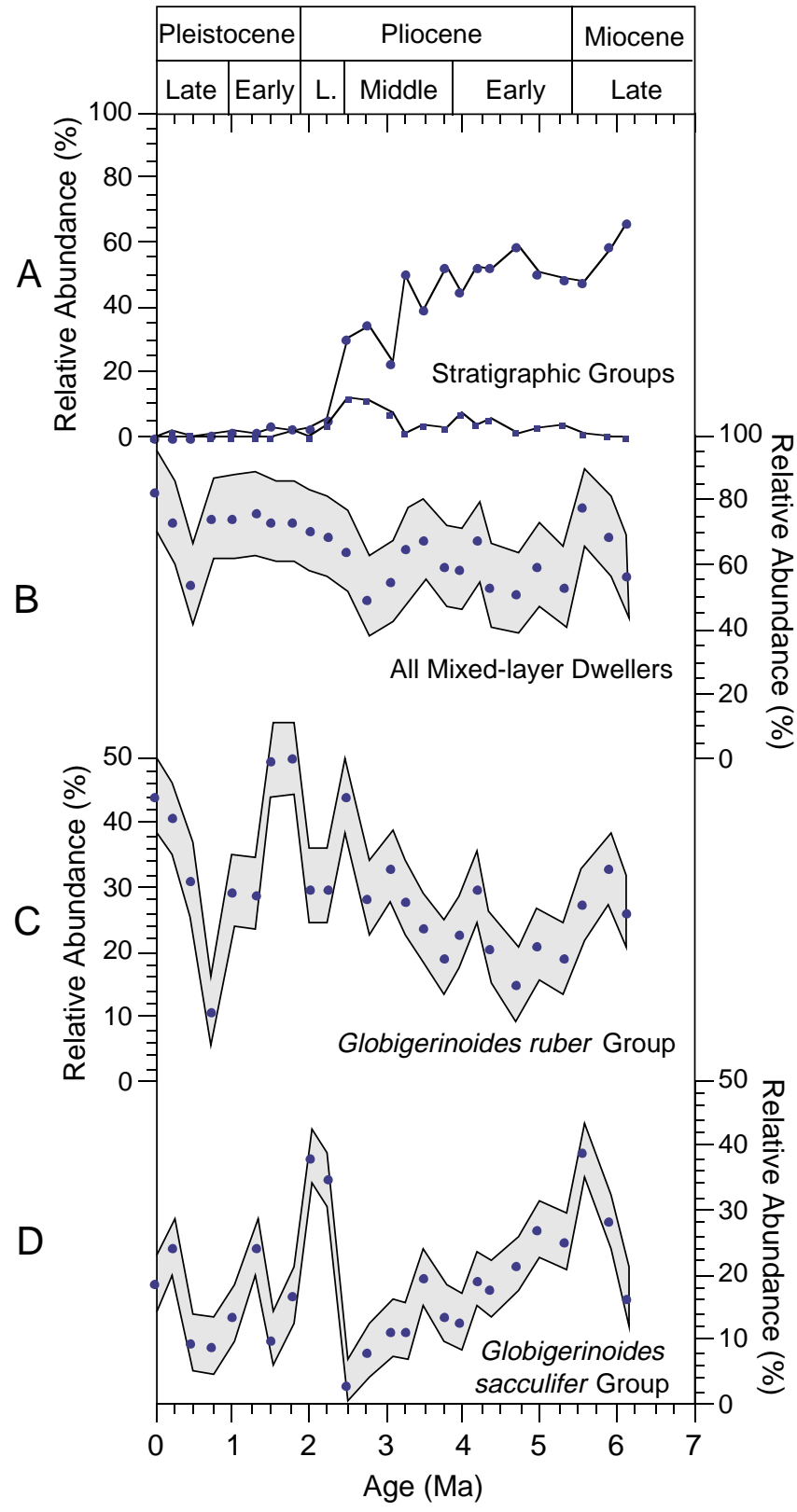

Figure 5. Relative abundance of stratigraphic groups, Miocene-Pliocene (circles) and Pliocene-Pleistocene (squares) (A), and mixed-layer dwelling groups $(\mathbf{B}, \mathbf{C}, \mathbf{D})$. Gray areas represent two standard deviations, and are based on high-resolution data from Pliocene intervals in the Pacific (Chaisson, 1996).

ened wind fields, caused southeast tradewinds to "pile" warm surface water on the western side of the basin, and depressed the thermocline.

Warmer, interglacial conditions prevailed in Antarctica between 5.5 and 3.2 Ma (Hodell and Kennett, 1986; Jansen et al., 1993). The character of faunal and isotopic records at Site 925 changes to reflect the accompanying decrease in tradewind strength in the low latitudes from the late Miocene to early Pliocene. Three thermocline-dwelling groups increase to the abundance maxima between 5.57 and $3.78 \mathrm{Ma}$ (Figs. 7B, C, D). The ML $\Delta \delta^{18} \mathrm{O}$ record shows a steep decrease between 5.57 and 5.31 Ma. Smaller ML $\Delta \delta^{18} \mathrm{O}$ values show that the temperature difference between Globigerinoides sacculifer and Neogloboquadrina dutertrei habitats decreased. Decreased advection of warm surface water to the western tropical Atlantic allowed the ther-

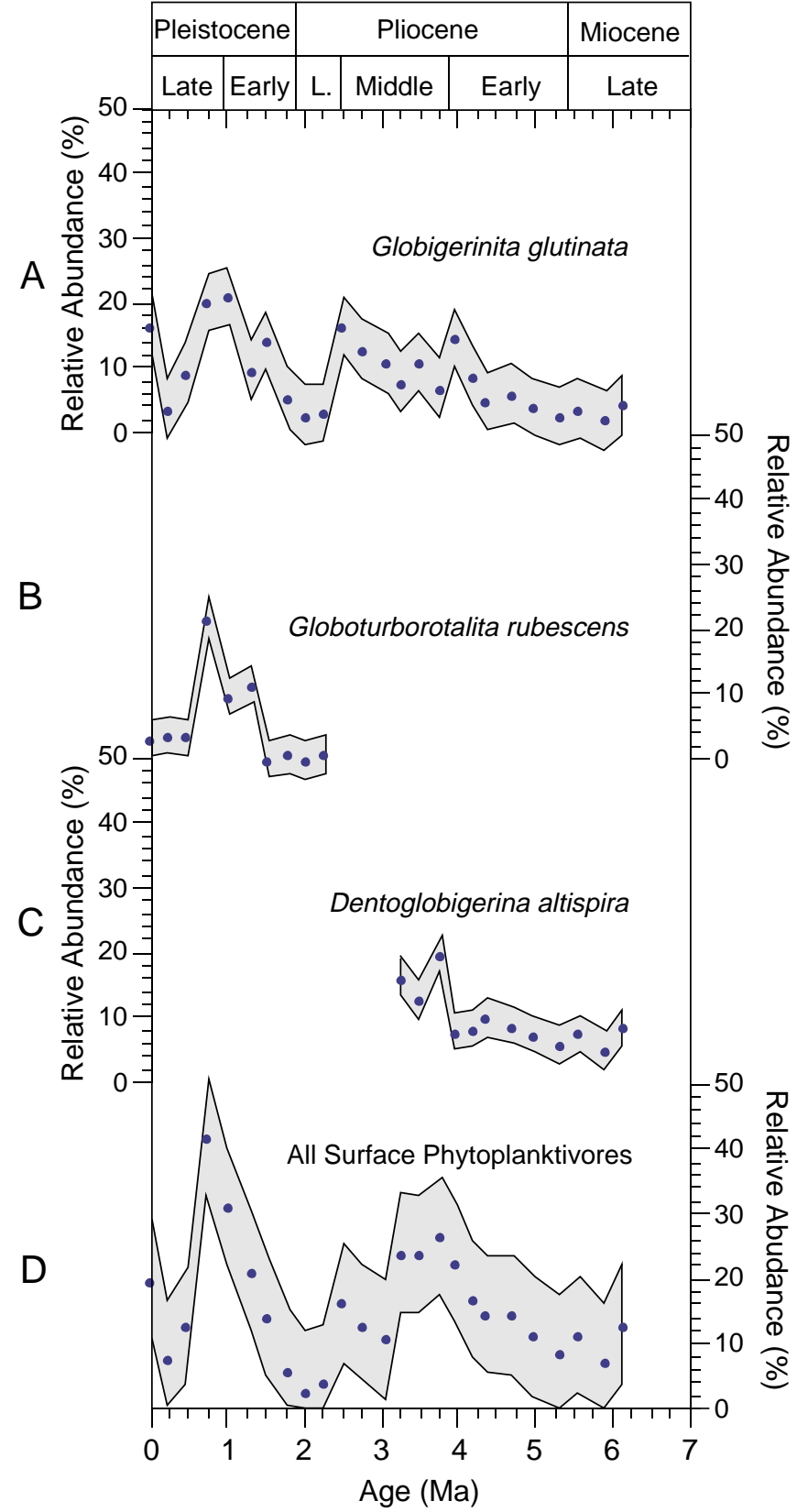

Figure 6. Relative abundance of the surface phytoplanktivores. The last group represents the sum of the previous three species. Gray areas as in Fig. 5 .

mocline to shoal higher in the photic zone and decreased sea-surface temperatures (SST).

Eolian dust records indicate that the late Miocene to early Pliocene was a period of declining tradewind strength. In the western (Krissek and Janecek, 1993) and eastern (Hovan, 1995) equatorial Pacific, grain size of eolian material decreased between 5.5 and 4.0 Ma. In the eastern tropical Atlantic (Tiedemann et al., 1989, 1994), dust flux reached a minimum value for the Pliocene at approximately 4.0 Ma.

Jansen et al. (1993) attributed a positive drift in Globigerinoides sacculifer $\delta^{18} \mathrm{O}$ after $3.7 \mathrm{Ma}$ at Site 806 in the western equatorial $\mathrm{Pa}$ cific to the growth of Northern Hemisphere ice sheets. The $\delta^{18} \mathrm{O}$ records of both $G$. sacculifer and $N$. dutertrei (Fig. 2) also show a strong positive drift at Site 925 after $3.78 \mathrm{Ma}$, recording the global 


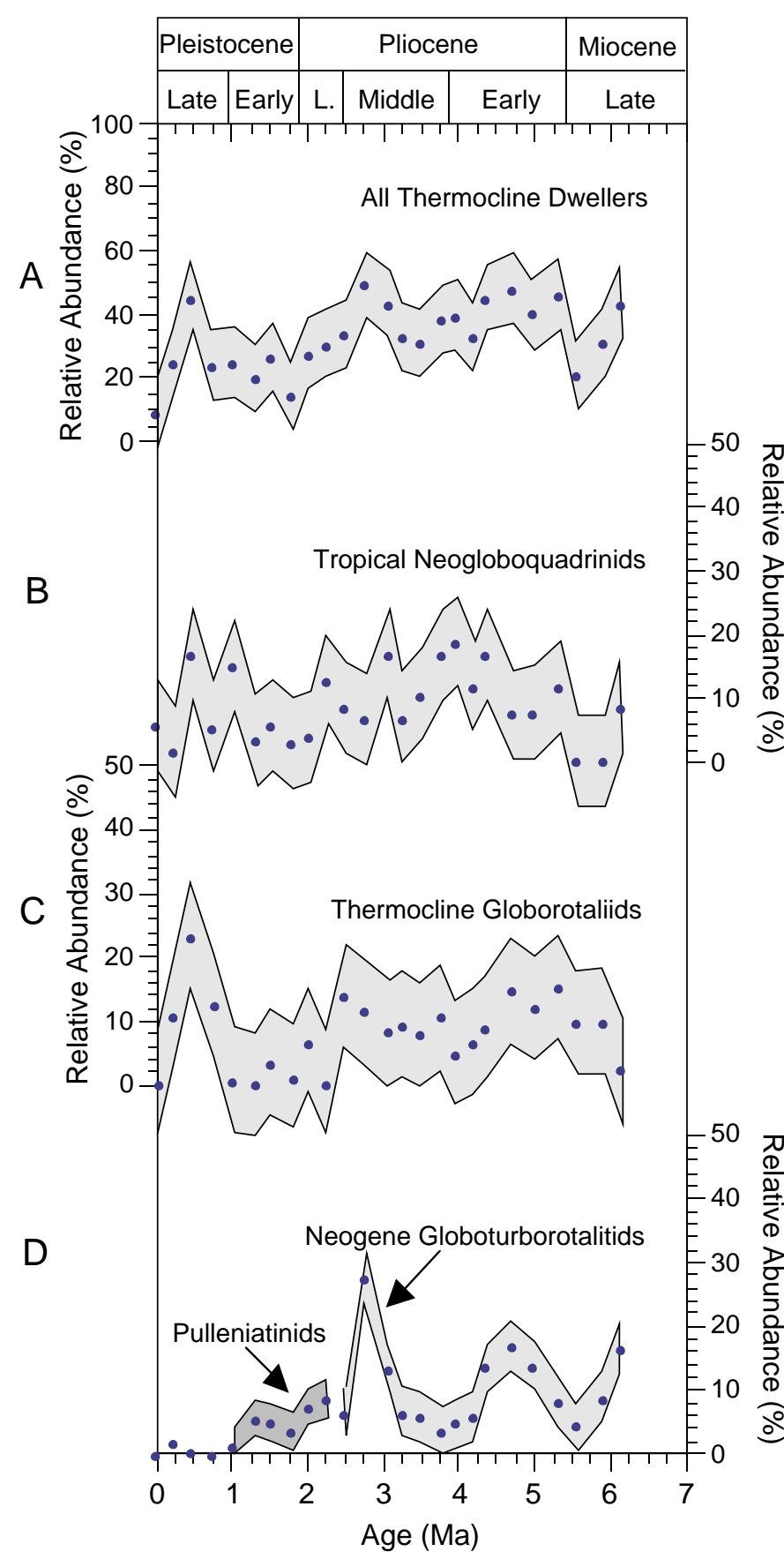

Figure 7. Relative abundance of thermocline dwelling faunal groups. Gray areas as in Fig. 5.

trend noted by Jansen et al. (1993). A trend in upper water-column conditions at Site 925 is revealed by the increase of ML $\Delta \delta^{18} \mathrm{O}$ values between 4.19 and $1.80 \mathrm{Ma}$, which represents a growing temperature difference between $G$. sacculifer and $N$. dutertrei habitats.

Between 3.49 Ma and 2.00 Ma, ML $\Delta \delta^{13} \mathrm{C}$ values declined (Fig. $4 \mathrm{C}$ ), indicating that the $\delta^{13} \mathrm{C}$ gradient in the upper water column was declining through this interval. The larger part of the change in the ML $\Delta \delta^{13} \mathrm{C}$ record is due to the decline in G. sacculifer $\delta^{13} \mathrm{C}$ values (Fig. 3). There is no significant trend in the global carbon budget through this interval (Mix et al., 1995), and the decline in surface $\delta^{13} \mathrm{C}$ values is likely due to a decrease in productivity at Site 925 , which is also suggested by the overall decline in both tropical neogloboquadrinid and surface phytoplanktivore abundance (Fig. 7B), and the large increase in the Globigerinoides ruber group abundance (Fig. 5C) after the early Pliocene. Through this interval, the abundance of Miocene species at Site 925 declines from approximately $50 \%$ of the assemblage to near absence. The decline of this group in the equatorial Pacific (Sites 806 and 847) began after 4.5 Ma (Chaisson, 1996). Conditions favorable to species that evolved in the Miocene were evidently favorable into the middle Pliocene in the western tropical Atlantic. The nature of those conditions is unknown, although the general correlation with the ML $\Delta \delta^{13} \mathrm{C}$ record at Site 925 suggests that nutrient distribution in the upper water column may have been a factor.

TH $\Delta \delta^{18} \mathrm{O}$ and TH $\Delta \delta^{13} \mathrm{C}$ records provide further evidence of surface warming and increasing oligotrophy at Site 925 through the midand late Pliocene. Truncorotalia crassaformis $\delta^{18} \mathrm{O}$ values generally decreased between 3.78 and $2.24 \mathrm{Ma}$, in spite of a global trend toward increased $\delta^{18} \mathrm{O}$ values. TH $\Delta \delta^{18} \mathrm{O}$ values declined sharply as $N$. dutertre $i$ and T. crassaformis habitats converged. In the equatorial Atlantic, $T$. crassaformis is found between 150 and $200 \mathrm{~m}$ depth in association with the oxygen minimum zone (OMZ; Jones, 1967). Declining surface productivity and thickening of the mixed layer would have the effect of weakening the OMZ and depressing a warmer portion of the thermocline into $T$. crassaformis habitat. The absence of this species in samples at 2.00 and 1.80 Ma probably records the culmination of this trend. This interpretation is supported by the high numbers of both Globigerinoides groups in these samples (Figs. 5C, D). The maximum in pulleniatinid numbers at $2.24 \mathrm{Ma}$ is another indication of oligotrophic conditions at Site 925 . This group is most abundant in the deep, nutrient-poor thermocline waters of the western equatorial Pacific (Parker and Berger, 1971; Kennett et al., 1985; Whitman and Berger, 1993).

\section{Late Pliocene and Pleistocene}

The low resolution of sampling in this study prevents detailed interpretation of a relationship between faunal and isotopic evidence and upper water-column hydrography. However, some general observations are possible. The large late Pliocene increase in Truncorotalia crassaformis $\delta^{18} \mathrm{O}$ values (also noted by Spencer-Cervato, pers. comm., 1995) in the southwest Pacific suggests either a genetic change in this species or substantial cooling of upper intermediate water at this time. Further investigation is necessary before conclusions can be drawn. ML $\Delta \delta^{18} \mathrm{O}$ values remained elevated until the latest Pleistocene $(0.22$ and $0.01 \mathrm{Ma})$. Unlike the early Pliocene decrease in ML $\Delta \delta^{18} \mathrm{O}$ values, this event is coupled with a decrease in thermocline-dweller abundance (Figs. 4C, 7A, 7B, 7C). Faunal and isotopic evidence suggest an increase in downwelling and a warming of sub-subsurface water rather than shoaling of the thermocline and cooling of surface water.

Downwelling is also suggested by the sharp increase in $\mathrm{TH} \Delta \delta^{13} \mathrm{C}$ in the latest Pleistocene at Site 925 . The $\delta^{13} \mathrm{C}$ gradient was steepest between Globigerinoides sacculifer and Neogloboquadrina dutertrei habitat in the Pliocene of Site 925 (Fig. 4C), averaging nearly $1.5 \%$ in the early Pliocene. The decline of ML $\Delta \delta^{13} \mathrm{C}$ and the rise of TH $\Delta \delta^{13} \mathrm{C}$ suggests a downward movement of the $\delta^{13} \mathrm{C}$ gradient through the Pliocene into the Pleistocene at Site 925. Downwelling of surface water relatively rich in ${ }^{13} \mathrm{C}$ has the effect of making G. sacculifer and $N$. dutertrei $\delta^{13} \mathrm{C}$ values more similar, and $N$. dutertrei and Truncorotalia crassaformis $\delta^{13} \mathrm{C}$ values more dissimilar (Fig. 3).

The large sampling interval used for this study attaches too much uncertainty to the faunal and isotopic values to make regression analysis informative. Therefore, the isotopic values are divided into three classes, and threshold abundances are recognized for each faunal group. The interrelationships between the abundance fluctuations 
of the faunal groups and the values of the isotopic difference curves are summarized in Table 7 . Table 7 suggests that variations in the thermal gradient implied by the $\delta^{18} \mathrm{O}$ gradients in the mixed layer (ML $\Delta \delta^{18} \mathrm{O}$ ) and thermocline ( $\mathrm{TH} \Delta \delta^{18} \mathrm{O}$ ) can be reliably associated with high numbers (i.e., favorable environmental conditions and consequent reproductive success) of these faunal groups. The descriptions of tradewind and convergence strength, SST and strength, depth, and variability of the seasonal thermocline in Table 8 are based on inferences drawn from the associations of faunal and isotopic values presented in Table 7. In Table 8 , increasing ML $\Delta \delta^{18} \mathrm{O}$ values (top to bottom) are associated with warmer SSTs and stronger tradewinds. Increasing $\mathrm{TH} \Delta \delta^{18} \mathrm{O}$ values (left to right) are associated with a stronger and more seasonally variable thermocline. These paleoenvironmental deductions are applied only to Site 925, where increased tradewinds advect surface water, warm SSTs, and depress the thermocline. At sites on the eastern side of the equatorial Atlantic, in- creased tradewinds would be expected to cool SSTs and shoal the thermocline.

In the modern ocean, Site 925 is on the edge of a weak upwelling zone during the boreal summer and is beneath downwelling for the rest of the year (Hastenrath and Lamb, 1977; Molinari and Johns, 1994). Faunal data suggest that upwelling was never strong at Site 925 during the last 6 m.y.; tropical neogloboquadrinids never account for more than $20 \%$ of the assemblage. Rather, downwelling was at a minimum in the early Pliocene and gradually increased in strength and duration into the Pleistocene. Hastenrath (1985) noted that the SST maximum in the tropical Atlantic coincides with the convergence maximum. Increasingly large values of ML $\Delta \delta^{18} \mathrm{O}$ between the early Pliocene and early Pleistocene are coupled with decreases in the abundance of thermocline-dwelling fauna. These coinciding trends argue for increasing SST due to southward migration of the average position of the ITCZ (Fig. 8).

Table 7. Relating faunal abundance and isotopic gradients.

\begin{tabular}{|c|c|c|c|c|}
\hline & \multicolumn{4}{|c|}{ Thermocline } \\
\hline \multirow{5}{*}{ 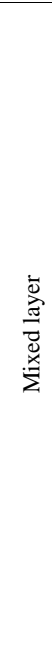 } & \multirow{2}{*}{\multicolumn{4}{|c|}{$\begin{array}{c}\text { Moderate } \\
\text { Dominant faunal groups }\end{array}$}} \\
\hline & & & & \\
\hline & Small & $\begin{array}{c}\text { Globigerinoides sacculifer } \text { group } \\
* \\
\text { Neogene } \\
\text { globoturborotalitids } \\
\text { Thermocline } \\
\text { globorotaliids }\end{array}$ & $\begin{array}{c}\text { Globigerinoides sacculifer } \text { group } \\
* \\
\text { Thermocline } \\
\text { globorotaliids }\end{array}$ & $\begin{array}{c}\text { Globigerinoides ruber group } \\
* \\
\text { Thermocline } \\
\text { globorotaliids }\end{array}$ \\
\hline & Moderate & $\begin{array}{c}\text { Globoturborotalita rubescens } \\
\text { Globigerinita glutinata } \\
* \\
\text { Neogene globoturborotalitids } \\
\text { Pulleniatinids }\end{array}$ & $\begin{array}{c}\text { Dentoglobigernia altispira } \\
\text { Globigerinita glutinata } \\
* \\
\text { Tropical neogloboquadrinids }\end{array}$ & $\begin{array}{c}\text { Globigerinoides ruber } \text { group } \\
\text { Globigerinita glutinata } \\
* \\
\text { Tropical neogloboquadrinids }\end{array}$ \\
\hline & Large & $?$ & $\begin{array}{c}\text { Globigerinia glutinata } \\
* \\
\text { Tropical neogloboquadrinids }\end{array}$ & $\begin{array}{c}\text { Globigerinoides ruber } \text { group } \\
\text { Globigerinita glutinata } \\
* \\
\text { Tropical neogloboquadrinids } \\
\text { Menardella menardii }\end{array}$ \\
\hline
\end{tabular}

Note: Faunal groups are considered to be dominant at varying levels: $>30 \%$ for the Globigerinoides ruber group, $>20 \%$ for the Globigerinoides sacculifer group, and $>15 \%$ for all other groups, except for the thermocline globorotaliids $(>10 \%)$ and the pulleniatinids $(>5 \%)$. Mixed-layer groups are above the asterisk and thermocline-dwelling groups below.

Table 8. Interpreting climatic and oceanographic conditions.

\begin{tabular}{|c|c|c|c|c|}
\hline & & \multicolumn{3}{|c|}{ Thermocline } \\
\hline & & Small & Moderate & Large \\
\hline \multirow{3}{*}{ 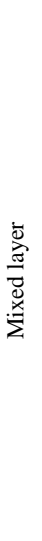 } & Small & $\begin{array}{c}\text { Tradewinds weak } \\
\text { (NE < SE) } \\
\text { Cooler SST } \\
\text { Convergence weak } \\
\text { Weak, deep } \\
\text { seasonal thermocline }\end{array}$ & $\begin{array}{c}\text { Tradewinds weak } \\
\text { (NE < SE) } \\
\text { Cooler SST } \\
\text { Convergence weak } \\
\text { Stronger, deep } \\
\text { seasonal thermocline }\end{array}$ & $\begin{array}{c}\text { Tradewinds weak } \\
\text { (NE < SE) } \\
\text { Cooler SST } \\
\text { Convergence weak } \\
\text { Seasonally variable } \\
\text { strong thermocline }\end{array}$ \\
\hline & Moderate & $\begin{array}{c}\text { Tradewinds weak } \\
(\mathrm{NE}<\mathrm{SE}) \\
\text { Warmer SST } \\
\text { Weaker seasonal } \\
\text { thermocline; } \\
\text { base of photic zone }\end{array}$ & $\begin{array}{c}\text { Tradewinds moderate } \\
\text { (NE = SE) } \\
\text { Warmer SST } \\
\text { Moderately variable } \\
\text { seasonal thermocline; } \\
\text { base of photic zone }\end{array}$ & $\begin{array}{c}\text { Tradewinds moderate } \\
(\mathrm{NE}=\mathrm{SE}) \\
\text { Warmer SST } \\
\text { Highly variable } \\
\text { seasonal thermocline; } \\
\text { base of photic zone }\end{array}$ \\
\hline & Large & $\begin{array}{c}\text { Tradewinds strong } \\
\text { Warmest SST } \\
\text { Weaker seasonal thermocline; } \\
\text { base of photic zone }\end{array}$ & $\begin{array}{c}\text { Tradewinds strong } \\
\text { Warmest SST } \\
\text { Moderately variable seasonal } \\
\text { thermocline; base of photic zone }\end{array}$ & $\begin{array}{c}\text { Tradewinds strong } \\
\text { Warmest SST } \\
\text { Highly variable seasonal } \\
\text { thermocline; base of photic zone }\end{array}$ \\
\hline
\end{tabular}




\section{CONCLUSIONS}

Planktonic foraminifer counts from undissolved sediments preserve a record of the relative reproductive success of each species. Isotopic measurements of multiple species document the isotopic gradients that are associated with the abundances in those samples. If these isotopic gradients are interpreted as thermal $\left(\Delta \delta^{18} \mathrm{O}\right)$ and nutrient $\left(\Delta \delta^{13} \mathrm{C}\right)$ gradients within the euphotic zone, then an association can be made between the reproductive success of certain species, or groups of species, and a particular physical environment. Many studies in the modern ocean that link the distribution of assemblages with the extent of particular water masses (e.g., Bé and Tolderlund, 1971; CLIMAP, 1981) have laid the groundwork for interpreting this relationship in the geologic past.

Small $\delta^{18} \mathrm{O}$ gradients in the mixed layer (ML $\Delta \delta^{18} \mathrm{O}$ ) are associated with high numbers of Globigerinoides species, while larger gradi-
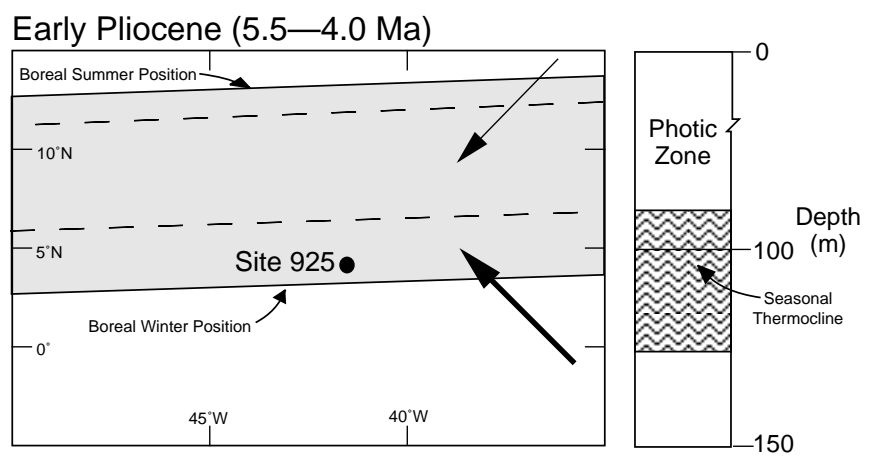

Middle to Late Pliocene (4.0-2.5 Ma)

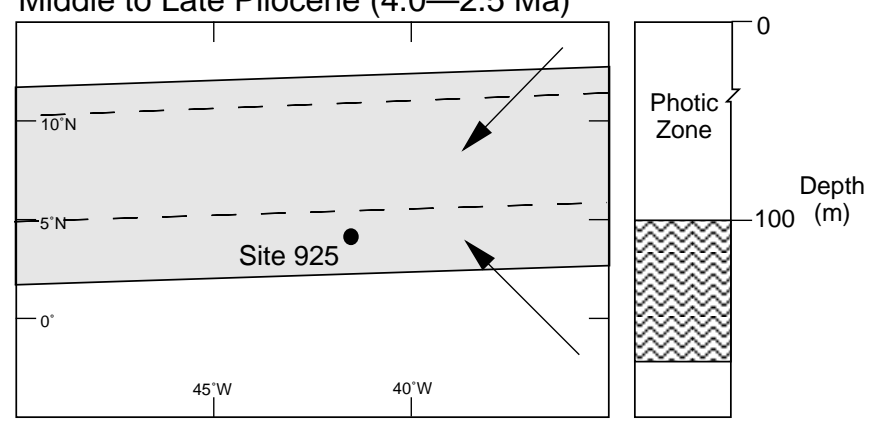

Pleistocene $(2.0-0.75 \mathrm{Ma})$

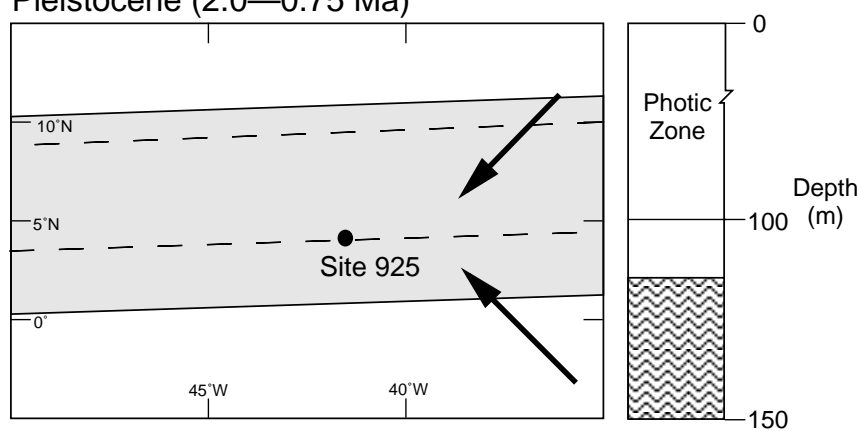

Figure 8. Three stages of paleoceanographic development at Site 925 in the western tropical Atlantic. The area between the extreme northern and southern positions of the intertropical convergence zone (ITCZ) is shaded. The dashed lines indicate the zone of maximum convergence. Large arrows indicate tradewind direction. The weight of the arrow represents wind strength. The concurrent position of the seasonal thermocline is indicated in the accompanying figures on the right. The uppermost portion of the thermocline $\left(\sim 20^{\circ}-15^{\circ} \mathrm{C}\right)$ is shown as dark shading. ents are associated with high numbers of surface phytoplanktivores (Tables 4,5). This concurs with what is observed in the modern ocean (e.g., Bé and Tolderlund, 1971); Globigerinoides spp. favor a less thermally stratified mixed layer. Larger gradients between the top of the seasonal thermocline and sub-thermocline water $\left(\mathrm{TH} \Delta \delta^{18} \mathrm{O}\right)$ are associated with larger numbers of the $G$. ruber group. In the modern ocean, G. ruber is more common at subtropical latitudes than is $G$. sacculifer (Bé, 1977), suggesting that it tolerates more seasonal change in the water column. Larger values of $\mathrm{TH} \Delta \delta^{18} \mathrm{O}$ may, therefore, be indicative of greater seasonal change in the structure of the water column at Site 925 . This conclusion is complemented by the association of larger numbers of pulleniatinids with small values of TH $\Delta \delta^{18} \mathrm{O}$. In the modern ocean, this thermocline-dwelling group is most common in the western equatorial Pacific, an area of minimal seasonality (Parker and Berger, 1971). By contrast, the greatest number of tropical neogloboquadrinids are associated with moderate to large values of ML and TH $\Delta \delta^{18} \mathrm{O}$ at Site 925 , that is, with the most thermal stratification of the euphotic zone. This pattern agrees with the biogeography of Neogloboquadrina dutertrei in the modern ocean, where it is more common in the eastern tropical regions and along eastern boundary currents (Bé, 1977; Parker and Berger, 1971), where there is seasonal or persistent upwelling.

When viewed in time series (Figs. 4-8), the above connections between planktonic foraminifer ecology and the structure of the upper water column suggest that during the last $6 \mathrm{~m}$.y. at Site 925, the thermocline shoaled to its shallowest levels near the early to midPliocene boundary (3.8 Ma). Numbers of tropical neogloboquadrinids are highest through this interval, but do not exceed $20 \%$ of the assemblage, which is similar to their representation in a core top from V29-144 in the eastern tropical Atlantic, where they calcify between 25 and 75 m (Ravelo and Fairbanks, 1992). Mix et al. (1995) show a $\sim 1.5 \%$ o increase in benthic $\delta^{18} \mathrm{O}$ values between the mid-Pliocene and the Pleistocene at Site 849 . This range is approximated by the $\delta^{18} \mathrm{O}$ values of Neogloboquadrina dutertrei through the comparable interval at Site 925, while the change in Globigerinoides sacculifer values is smaller. This suggests that at Site 925 the increase in G. sacculifer $\delta^{18} \mathrm{O}$ due to the increase in ice volume between the Pliocene and Pleistocene was off-set by a regional increase in SST. The increase in ML $\Delta \delta^{18} \mathrm{O}$ at Site 925 is therefore interpreted as largely due to an increase in SST. This evidence is coupled with an overall increase in the abundance of mixed-layer dwellers, driven by a very large increase in the number of G. ruber in the sediments after 2 Ma.

The faunal and isotopic data in this study suggest that the thermocline in this region $\left(4^{\circ} \mathrm{N}, 43^{\circ} \mathrm{W}\right)$ has been gradually depressed since $\sim 4 \mathrm{Ma}$, and that SST has gradually increased. We conclude that the cause for these oceanographic changes was the southward movement of the winter position of the ITCZ, and the downwelling and SST maximum that characterize the surface ocean below this atmospheric feature. This southward movement was a result of the progressive cooling of the northern hemisphere between the Pliocene and Pleistocene.

\section{ACKNOWLEDGMENTS}

Thanks to the rest of the scientific party of Leg 154 and to the crew of the SEDCO Forex 491 for (what was in hindsight) a perfect cruise. The first author thanks the second author for the use of the UCSC mass spectrometer. The research for this paper was made possible by a post-cruise grant from JOI/ USSSP.

\section{REFERENCES}

Backman, J., 1979. Pliocene biostratigraphy of DSDP Sites 111 and 116 from the North Atlantic Ocean and the age of Northern Hemisphere Glaciation. Stockholm Contrib. Geol., 32:115-137.

Bé, A.W.H., 1960. Ecology of recent planktonic Foraminifera, Part 2. Bathymetric and season distributions in the Sargasso Sea off Bermuda. Micropaleontology, 6:144-151. 
1977. An ecological, zoogeographic and taxonomic review of Recent planktonic foraminifera. In Ramsay, A.T.S. (Ed.), Oceanic Micropaleontology (Vol. 1): London (Acad. Press), 1-100.

Bé, A.W.H., Hemleben, C., Anderson, O.R., Spindler, M., Hacunda, J., and Tuntivate-Choy, S., 1977. Laboratory and field observations of living planktonic foraminifera. Micropaleontology, 23:155-179.

Bé, A.W.H., van Donk, J., Hecht, A.D., and Savin, S., 1971. Oxygen-18 studies of Recent planktonic foraminifers. Science, 173:167-169.

Bé, A.W.H., and Tolderlund, D., 1971. Distribution and ecology of living planktonic foraminifera in surface waters of the Atlantic and Indian Oceans. In Funnell, B., and Riedel, W., (Eds.), Micropaleontology of the Oceans: Cambridge (Cambridge University Press).

Berger, W.H., 1971. Sedimentation of planktonic foraminifera. Mar. Geol., 11:325-358.

Berger, W.H., Killingley, J.S., and Vincent, E., 1978. Stable isotopes in deepsea carbonates: box cores ERDC-92, west equatorial Pacific. Oceanol. Acta, 1:203-216.

Berggren, W.A., 1972. Late Pliocene-Pleistocene glaciation. In Laughton, A.S., Berggren, W.A., et al., Init. Repts. DSDP, 12: Washington (U.S. Govt. Printing Office), 953-963.

Berggren, W.A., and Hollister, C.D., 1977. Plate tectonics and paleocirculation: commotion in the ocean. Tectonophysics, 38:11-48.

Bolli, H.M., and Saunders, J.B., 1985. Oligocene to Holocene low latitude planktonic foraminifera. In Bolli, H.M., Saunders, J.B., and PerchNielsen, K. (Eds.), Plankton Stratigraphy: Cambridge (Cambridge Univ. Press), 155-262.

Chaisson, W., 1995. Planktonic foraminiferal assemblages and paleoceanographic change in the trans-tropical Pacific Ocean: a comparison of west (Leg 130) and east (Leg 138), latest Miocene to Pleistocene. In Pisias, N.G., Mayer, L.A., Janecek, T.R., Palmer-Julson, A. and van Andel, T.H. (Eds.), Proc. ODP, Sci. Results, 138: College Station, TX (Ocean Drilling Program), 555-597.

Chaisson, W.P., 1996. Equatorial Atlantic and Pacific Paleoceanography, Late Miocene to Pleistocene [Ph.D. dissert.]. Univ. of Massachusetts, Amherst.

Chaisson, W.P., and Leckie, R.M., 1993. High-resolution Neogene planktonic foraminifer biostratigraphy of Site 806, Ontong Java Plateau (western equatorial Pacific). In Berger, W.H., Kroenke, L.W., Mayer, L.A., et al., Proc. ODP, Sci. Results, 130: College Station, TX (Ocean Drilling Program), 137-178

Ciesielski, P.F., Ledbetter, M.T., and Ellwood, B.B., 1982. The development of Antarctic glaciation and the Neogene paleoenvironment of the Maurice Ewing Bank. Mar. Geol., 46:1-51.

CLIMAP, 1981. Seasonal reconstruction of the earth's surface at the last glacial maximum. Geol. Soc. Am. Map and Chart Ser., MC-36.

Coates, A.G., Jackson, J.B., Collins, L.S., Cronin, T.M., Dowsett, H.J., Bybell, L.M., Jung, P., and Obando, J.A., 1992. Closure of the Isthmus of Panama: the near-shore marine record of Costa Rica and Western Panama. Geol. Soc. Am. Bull., 104:814-828.

Curry, W.B., and Matthews, R.K., 1981. Paleoceanographic utility of oxygen isotopic measurements on planktonic foraminifera: Indian Ocean core top evidence. Palaeogeogr., Palaeoclimatol., Palaeoecol., 33:173-192.

Curry, W.B., Thunell, R.C., and Honjo, S., 1983. Seasonal changes in the isotopic composition of planktonic foraminifera collected in Panama Basin sediment traps. Earth Planet. Sci. Lett., 64:33-43.

Curry, W.B., Shackleton, N.J., Richter, C., et al., 1995. Proc. ODP, Init. Results, 154: College Station, TX (Ocean Drilling Program).

Deuser, W.G., 1987. Seasonal variations in isotopic composition and deepwater fluxes of the tests of perennially abundant planktonic foraminifera of the Sargasso Sea: results from sediment-trap collections and their paleoceanographic significance. J. Foraminiferal Res., 17:14-27.

Deuser, W.G., and Ross, E.H., 1989. Seasonally abundant planktonic Foraminifera of the Sargasso Sea: succession, deep-water fluxes, isotopic compositions, and paleoceanographic implications. J. Foraminiferal Res., 19:268-293.

Deuser, W.G., Ross, E.H., Hemleben, C., and Spindler, M., 1981. Seasonal changes in species composition numbers, mass, size and isotopic composition of planktonic foraminifera settling into the deep Sargasso Sea. Palaeogeogr., Palaeoclimatol., Palaeoecol., 33:103-127.

Douglas, R.G., and Savin, S.M., 1978. Oxygen isotopic evidence for the depth stratification of Tertiary and Cretaceous planktic Foraminifera. Mar. Micropaleontol., 3:175-196.

Dowsett, H.J., and Poore, R.Z., 1990. A new planktic foraminifer transfer function for estimating Pliocene-Holocene paleoceanographic conditions in the North Atlantic. Mar. Micropaleontol., 16:1-23.
Duque-Caro, H., 1990. Neogene stratigraphy, paleoceanography and paleobiogeography in the northwest South America and the evolution of the Panama Seaway. Palaeogeogr., Palaeoclimatol., Palaeoecol., 77:203234.

Durazzi, J.I., 1981. Stable isotope studies of planktonic foraminifera in North Atlantic core tops. Palaeogeogr., Palaeoclimatol., Palaeoecol., 33:157172.

Emiliani, C., 1954. Depth habitats of some species of pelagic foraminifera as indicated by oxygen isotope ratios. Am. J. Sci., 252:149-158.

1971. Depth habitats of growth stages of pelagic foraminifera. Science, 173:1122-1124.

Fairbanks, R.G., Sverdlove, M., Free, R., Wiebe, P.H., and Bé, A.W.H., 1982. Vertical distribution and isotopic fractionation of living planktonic foraminifera from the Panama Basin. Nature, 298:841-844.

Fairbanks, R.G., and Wiebe, P.H., 1980. Foraminifera and chlorophyll maximum: vertical distribution, seasonal succession, and paleoceanographic significance. Science, 209:1524-1526.

Fairbanks, R.G., Wiebe, P.H., and Bé, A.W.H., 1980. Vertical distribution and isotopic composition of living planktonic foraminifera in the western North Atlantic. Science, 207:61-63.

Farrell, J., Raffi, I., Janecek, T., Murray, D., Levitan, M., Dadey, K., Emeis, K.-C., Lyle, M., Flores, J.-A., and Hovan, S., 1995. Late Neogene sedimentation patterns in the eastern equatorial Pacific Ocean (Leg 138). In Pisias, N.G., Mayer, L.A., Janecek, T.R., Palmer-Julson, A., and van Andel, T. H. (Eds.), Proc. ODP, Sci. Results, 138: College Station, TX (Ocean Drilling Program).

Gasperi, J.T., and Kennett, J.P., 1992. Isotopic evidence for depth stratification and paleoecology of Miocene planktonic Foraminifera: western equatorial Pacific DSDP Site 289. In Tsuchi, R., and Ingle, J.C., Jr. (Eds.), Pacific Neogene-Environment, Evolution, and Events: Tokyo (Univ. of Tokyo Press), 117-147.

1993. Miocene planktonic foraminifers at DSDP Site 289: depth stratification using isotopic differences. In Berger, W.H., Kroenke, L.W., Mayer, L.A., et al., Proc. ODP, Sci. Results, 130: College Station, TX (Ocean Drilling Program), 323-332.

Haq, B.U., 1984. Paleoceanography: a synoptic overview of 200 million years of ocean history. In Haq, B.U., and Milliman, J.D. (Eds.), Marine Geology and Oceanography of Arabian Sea and Coastal Pakistan: New York (Van Nostrand Reinhold), 201-231.

Hastenrath, S., 1985. Climate and Circulation of the Tropics: Boston (Reidel).

Hastenrath, S., and Lamb, P.J., 1977. Climatic Atlas of the Tropical Atlantic and Eastern Pacific Oceans: Madison, WI (University of Wisconsin Press).

Hecht, A.D., and Savin, S.M., 1972. Phenotypic variation and oxygen isotope ratios in Recent planktonic Foraminifera. J. Foraminiferal Res., 2:55-67.

Hemleben, C., and Spindler, M., 1983. Recent advances in research on living planktonic Foraminifera In Meulenkamp, J.E. (Ed.), Reconstruction of Marine Paleoenvironments. Utrecht Micropaleontol. Bull., 30:141-170.

Hemleben, C., Spindler, M., and Anderson, O.R., 1989. Modern Planktonic Foraminifera: Berlin (Springer-Verlag).

Hodell, D.A., Elmstrom, K.M., and Kennett, J.P., 1986. Latest Miocene benthic $\delta^{18} 0$ changes, global ice volume, sea level, and the "Messinian salinity crisis." Nature, 320:411-414.

Hodell, D.A., and Kennett, J.P., 1986. Late Miocene-early Pliocene stratigraphy and paleoceanography of the South Atlantic and southwest Pacific Oceans: a synthesis. Paleoceanography, 1:285-311.

Hodell, D.A., and Vayavananda, A., 1993. Middle Miocene paleoceanography of the western equatorial Pacific (DSDP Site 289) and the evolution of Globorotalia (Fohsella). Mar. Micropaleontol., 22:279-310.

Hovan, S.A., 1995. Late Cenozoic atmospheric circulation intensity and climatic history recorded by eolian deposition in the eastern equatorial Pacific Ocean, Leg 138. In Pisias, N.G., Mayer, L.A., Janecek, T.R., Palmer-Julson, A., and van Andel, T.H. (Eds.), Proc. ODP., Sci. Results, 138: College Station, TX (Ocean Drilling Program), 615-625.

Imbrie, J., and Kipp, N.G., 1971. A new micropaleontological method for quantitative paleoclimatology: application to a late Pleistocene Caribbean core. In Turekian, K.K. (Ed.), The Late Cenozoic Glacial Ages: New Haven, CT (Yale Univ. Press), 71-181.

Jansen, E., Mayer, L.A., Backman, J., Leckie, R.M., and Takayama, T., 1993. Evolution of Pliocene climate cyclicity at Hole 806B (5-2 Ma): oxygen isotope record. In Berger, W.H., Kroenke, L.W., Mayer, L.A., et al., Proc. ODP, Sci. Results, 130: College Station, TX (Ocean Drilling Program), 349-362. 
Jones, J.I., 1967. Significance of distribution of planktonic foraminifers in the Equatorial Atlantic Undercurrent. Micropaleontology, 13:489-501.

Kaneps, A.G., 1979. Gulf Stream: velocity fluctuations during the late Cenozoic. Science, 204:297-301.

Keigwin, L.D., Jr., 1978. Pliocene closing of the Isthmus of Panama, based on biostratigraphic evidence from nearby Pacific Ocean and Caribbean Sea cores. Geology, 6:630-634.

1979. Late Cenozoic stable isotope stratigraphy and paleoceanography of DSDP sites from the east equatorial and central North Pacific Ocean. Earth Planet. Sci. Lett., 45:361-382.

, 1982. Stable isotope stratigraphy and paleoceanography of Sites 502 and 503. In Prell, W.L., Gardner, J.V., et al., Init. Repts. DSDP, 68: Washington (U.S. Govt. Printing Office), 445-453.

Keller, G., 1985. Depth stratification of planktonic foraminifers in the Miocene ocean. In Kennett, J.P. (Ed.), The Miocene Ocean: Paleoceanography and Biogeography. Mem.-Geol. Soc. Am., 163:177-196.

Kennett, J.P., Keller, G., and Srinivasan, M.S., 1985. Miocene planktonic foraminiferal biogeography and paleoceanographic development of the Indo-Pacific region. In Kennett, J.P. (Ed.), The Miocene Ocean: Paleoceanography and Biogeography. Mem.-Geol. Soc. Am., 163:197236.

Kennett, J.P., and Srinivasan, M.S., 1983. Neogene Planktonic Foraminifera: A Phylogenetic Atlas: Stroudsburg, PA (Hutchinson Ross).

Kennett, J.P., and von der Borch, C.C., 1986. Southwest Pacific Cenozoic paleoceanography. In Kennett, J.P., von der Borch, C.C., et al., Init. Repts. DSDP, 90 (Pt. 2): Washington (U.S. Govt. Printing Office), 14931517.

Krissek, L.A., and Janecek, T.R., 1993. Eolian deposition on the Ontong Java Plateau since the Oligocene: unmixing a record of multiple dust sources. In Berger, W.H., Kroenke, L.W., Mayer, L.A., et al., Proc. ODP, Sci. Results, 130: College Station, TX (Ocean Drilling Program), 471-490.

Kroon, D., and Ganssen, G.M., 1988. Northern Indian Ocean upwelling cells and the stable isotope composition of living planktic foraminifers. In Brummer, G.-J.A. and Kroon, D. (Eds.), Planktonic Foraminifers as Tracers of Ocean Climate History: Amsterdam (VU Uitgeverij), 299, 318.

Leckie, R.M., 1989. An oceanographic model for the early evolutionary history of planktonic foraminifera. Palaeogeogr., Palaeoclimatol., Palaeoecol., 73:107-138.

Lidz, B., Kehm, A., and Miller, H., 1968. Depth habitats of pelagic foraminifera during the Pleistocene. Nature, 217:245-247.

Lohmann, G.P., 1995. A model of variation in the chemistry of planktonic foraminifers due to secondary calcification and selective dissolution. Paleoceanography, 10:445-458.

Lohmann, G.P., and Schweitzer, P.N., 1990. Globorotalia truncatulinoides' growth and chemistry as probes of the past thermocline: 1 . Shell size. Paleoceanography, 5:55-75.

Lourens, L.J., Hilgen, F.J., Gudjonsson, L., and Zachariasse, W.J., 1992. Late Pliocene to early Pleistocene astronomically forced sea surface productivity and temperature variations in the Mediterranean. Mar. Micropaleontol., 19:49-78.

MacArthur, R.H., Recher, H., and Cody, M., 1966. On the relation between habitat selection and species diversity. Am. Nat., 100:319-332.

McKenzie, J.A., and Oberhänsli, H., 1985. Paleoceanographic expressions of the Messinian salinity crisis. In Hsü, K.J., and Weissert, H.J. (Eds.), South Atlantic Paleoceanography: Cambridge (Cambridge Univ. Press), 99-123.

Mix, A.C., Pisias, N.G., Rugh, W., Wilson, J., Morey, A., and Hagelberg, T.K., 1995. Benthic foraminiferal stable isotope record from Site 849: 05 Ma. In Pisias, N.G., Mayer, L.A., Janecek, T.R., Palmer-Julson, A., and van Andel, T.H. (Eds.), Proc. ODP, Sci. Results, 138: College Station, TX (Ocean Drilling Program), 371-412.

Molinari, R.L., and Johns, E., 1994. Upper layer temperature structure of the western tropical Atlantic. J. Geophys. Res., 99:18,225-18,233.

Norris, R.D., Corfield, R.M., and Cartlidge, J.E., 1993. Evolution of depth ecology in the planktic foraminifera lineage Globorotalia (Fohsella). Geology, 21:975-978.

, 1994. Evolutionary ecology of Globorotalia (Globoconella) (planktic foraminifera). Mar. Micropaleontol., 23:121-145.

Parker, F.L., and Berger, W.H., 1971. Faunal and solution patterns of planktonic Foraminifera in surface sediments of the South Pacific. Deep-Sea Res. Part A, 18:73-107.

Poore, R.Z., 1981. Temporal and spatial distribution of ice-rafted mineral grains in Pliocene sediments of the North Atlantic: implications for late
Cenozoic climatic history. Spec. Publ.-Soc. Econ. Paleontol. Mineral., 32:505-515.

Ravelo, A.C., and Fairbanks, R.G., 1992. Oxygen isotopic composition of multiple species of planktonic foraminifera: recorders of the modern photic zone temperature gradient. Paleoceanography, 7:815-831.

Ravelo, A.C., Fairbanks, R.G., and Philander, G., 1990. Reconstructing tropical Atlantic hydrography using planktonic foraminifera and an ocean model. Paleoceanography, 5:409-431.

Raymo, M.E., Hodell, D., and Jansen, E., 1992. Response of deep ocean circulation to initiation of Northern Hemisphere glaciation (3-2 Ma). Paleoceanography, 7:645-672.

Raymo, M.E., Ruddiman, W.F., Backman, J., Clement, B.M., and Martinson, D.G., 1989. Late Pliocene variation in Northern Hemisphere ice sheets and North Atlantic deep water circulation. Paleoceanography, 4:413446.

Ricklefs, R.E., 1979. Ecology: New York (Chiron Press).

Saito, T., 1976. Geologic significance of coiling direction in the planktonic foraminifer Pulleniatina. Geology, 4:305-309.

Savin, S.M., and Douglas, R.G., 1973. Stable isotope and magnesium geochemistry of Recent planktonic foraminifera from the South Pacific. Geol. Soc. Am. Bull., 84:2327-2342.

Shackleton, N., 1967. Oxygen isotope analyses and Pleistocene temperatures re-assessed. Nature, 215:15-17.

Shackleton, N.J., Backman, J., Zimmerman, H., Kent, D.V., Hall, M.A., Roberts, D.G., Schnitker, D., Baldauf, J.G., Desprairies, A., Homrighausen, R., Huddlestun, P., Keene, J.B., Kaltenback, A.J., Krumsiek, K.A.O., Morton, A.C., Murray, J.W., and Westberg-Smith, J., 1984. Oxygen isotope calibration of the onset of ice-rafting and history of glaciation in the North Atlantic region. Nature, 307:620-623.

Shackleton, N.J., and Kennett, J.P., 1975. Late Cenozoic oxygen and carbon isotopic changes at DSDP Site 284: implications for glacial history of the Northern Hemisphere and Antarctica. In Kennett, J.P., Houtz, R.E., et al., Init. Repts. DSDP, 29: Washington (U.S. Govt. Printing Office), 801807.

Shackleton, N.J., and Opdyke, N.D., 1977. Oxygen isotope and palaeomagnetic evidence for early Northern Hemisphere glaciation. Nature, 270:216-219.

Shackleton, N.J., and Vincent, E., 1978. Oxygen and carbon isotope studies in recent foraminifera from the southwest Indian Ocean. Mar. Micropaleontol., 3:1-13.

Spindler, M., Hemleben, C., Salomons, J.B., and Smit, L.P., 1984. Feeding behavior of some planktonic foraminifers in laboratory cultures. J. Foraminiferal Res., 14:237-249.

Thunell, R., and Belyea, P., 1982. Neogene planktonic Foraminiferal biogeography of the Atlantic Ocean. Micropaleontology, 28:381-398.

Thunell, R.C., Curry, W.B., and Honjo, S., 1983. Seasonal variation in the flux of planktonic foraminifers: time series sediment trap results from the Panama Basin. Earth Planet. Sci. Lett., 64:44-55.

Thunell, R.C., and Reynolds, L.A., 1984. Sedimentation of planktonic foraminifera: seasonal changes in species flux in the Panama Basin. Micropaleontology, 30:243-262.

Thunell, R.C., and Williams, D.F., 1983. The step-wise development of Pliocene-Pleistocene paleoclimate and paleoceanographic conditions in the Mediterranean: oxygen isotope studies and DSDP Sites 125 and 132. In Meulenkamp, J.E. (Ed.), Reconstruction of Marine Paleoenvironments, Utrecht Micropaleontol. Bull., 30:111-127.

Tiedemann, R., Sarnthein, M., and Shackleton, N.J., 1994. Astronomic timescale for the Pliocene Atlantic $\delta^{18} \mathrm{O}$ and dust flux records of Ocean Drilling Program Site 659. Paleoceanography, 9:619-638.

Tiedemann, R., Sarnthein, M., and Stein, R., 1989. Climatic changes in the western Sahara: paleo-marine sediment record of the last 8 million years (Sites 657-661). In Ruddiman, W., Sarnthein, M., et al., Proc. ODP, Sci. Results, 108: College Station, TX (Ocean Drilling Program), 241-277.

Wei, K.-Y., and Kennett, J.P., 1986. Taxonomic evolution of Neogene planktonic foraminifera and paleoceanographic relations. Paleoceanography, $1: 67-84$.

Whitman, J.M., and Berger, W.H., 1993. Pliocene-Pleistocene carbon isotope record, Site 856, Ontong Java Plateau. In Berger, W.H., Kroenke, L.W., Mayer, L.A., et al., Proc. ODP, Sci. Results, 130: College Station, TX (Ocean Drilling Program), 333-348.

Williams, D.F., Bé, A.W.H., and Fairbanks, R.G., 1979. Seasonal oxygen isotopic variations in living planktonic foraminifera off Bermuda. Science, 206:447-449. 